Praca poglądowa/Review

\title{
Część I: Wytyczne postępowania w hemofilii A i B niepowikłanej inhibitorem czynnika VIII i IX (wydanie zaktualizowane)
}

\section{Part I: Guidelines on the management of Haemophilia $A$ and $B$ without factor VIII or IX inhibitors (updated edition)}

\author{
Jerzy Windyga ${ }^{1, *}$, Krzysztof Chojnowski ${ }^{2}$, Anna Klukowska ${ }^{3}$, \\ Magdalena Łętowska ${ }^{4}$, Andrzej Mital ${ }^{5}$, Jacek Musiał ${ }^{6}$, \\ Jarosław Peregud-Pogorzelski ${ }^{7}$, Maria Podolak-Dawidziak ${ }^{8}$, \\ Jacek Treliński ${ }^{2}$, Anetta Undas ${ }^{9}$, Tomasz Urasiński ${ }^{7}$, \\ Joanna Zdziarska ${ }^{10}$, Krystyna Zawilska ${ }^{11}$ \\ ${ }^{1}$ Klinika Zaburzeń Hemostazy i Chorób Wewnętrznych oraz Zakład Hemostazy i Chorób Metabolicznych Instytutu \\ Hematologii i Transfuzjologii $w$ Warszawie, Polska \\ ${ }^{2}$ Katedra i Klinika Hematologii Uniwersytetu Medycznego w Łodzi, Polska \\ ${ }^{3}$ Katedra i Klinika Pediatrii, Hematologii i Onkologii Warszawskiego Uniwersytetu Medycznego, Polska \\ ${ }^{4}$ Zakład Transfuzjologii Instytutu Hematologii I Transfuzjologii $w$ Warszawie, Polska \\ ${ }^{5}$ Katedra i Klinika Hematologii i Transplantologii Akademii Medycznej w Gdańsku, Polska \\ ${ }^{6}$ II Katedra Chorób Wewnętrznych, Uniwersytet Jagielloński Collegium Medicum, Polska \\ ${ }^{7}$ Klinika Pediatrii, Hematologii i Onkologii Dziecięcej Pomorskiego Uniwersytetu Medycznego w Szczecinie, Polska \\ ${ }^{8}$ Klinika Hematologii, Nowotworów Krwi i Transplantacji Szpiku, Uniwersytet Medyczny we Wrocławiu, Polska \\ ${ }^{9}$ Ośrodek Nowoczesnej Diagnostyki Laboratoryjnej Krakowski Szpital Specjalistyczny im. Jana Pawła II, Polska \\ ${ }^{10}$ Klinika Hematologii Szpitala Uniwersyteckiego w Krakowie, Polska \\ ${ }^{11}$ Pracownia Hemostazy Kliniki Hematologii i Chorób Rozrostowych Układu Krwiotwórczego Uniwersytetu \\ Medycznego im. Karola Marcinkowskiego w Poznaniu i Oddział Chorób Wewnętrznych i Hematologii Szpitala im. \\ J. Strusia w Poznaniu, Polska
}

INFORMACJE O ARTYKULE

Historia artykułu:

Otrzymano: 14.04 .2016

Zaakceptowano: 20.04.2016

Dostępne online: 28.04 .2016

Słowa kluczowe:

- hemofilia A
A B S T R A C T

In this document, Working Group for Haemostasis of the Polish Society of Haematology and Blood Transfusion updates the principles of diagnosis and treatment of haemophilia $A$ and $B$, published for the first time in 2008. In a companion paper (part II), the management of haemophilia A and B complicated by factor VIII and IX inhibitors will be covered.

() 2016 Polskie Towarzystwo Hematologów i Transfuzjologów, Instytut Hematologii i Transfuzjologii. Published by Elsevier Sp. z o.o. All rights reserved.

\footnotetext{
* Adres do korespondencji: Zakład Hemostazy i Chorób Metabolicznych Instytutu Hematologii i Transfuzjologii, ul. Gandhi 14, 02-776 Warszawa, Polska. Tel.: +48 223496481.

Adres email: jwindyga@ihit.waw.pl (J. Windyga).

http://dx.doi.org/10.1016/j.achaem.2016.04.009

0001-5814/@ 2016 Polskie Towarzystwo Hematologów i Transfuzjologów, Instytut Hematologii i Transfuzjologii. Published by Elsevier Sp. $\mathrm{z}$ o.o. All rights reserved.
} 
- hemofilia B

- profilaktyka

- krwawienia

- wytyczne

- Polska

- czynnik VIII

- czynnik IX

Keywords:

- Haemophilia A

- Haemophilia B

- Prophylaxis

- Bleeding

- Guidelines

- Poland

- Factor VIII

- Factor IX

\section{Cel Zasad postępowania}

Wrodzone skazy krwotoczne są rzadko występującymi chorobami, do rozpoznania których wykorzystuje się trudno dostępne techniki laboratoryjne, a w leczeniu krwawień stosuje się kosztowne leki hemostatyczne. Od opublikowania pierwszego wydania Wytycznych upłynęło 8 lat, w ciągu których nastąpił istotny postęp $\mathrm{w}$ leczeniu hemofilii [1]. Głównym celem obecnej pracy jest aktualizacja obowiązujących zasad postępowania w hemofilii A i B niepowikłanej inhibitorem czynnika VIII (factor VIII; FVIII) i czynnika IX (factor IX; FIX). Wytyczne zostały przygotowane w oparciu o opublikowane wyniki badań, a ich ostateczny kształt powstał podczas konferencji uzgodnieniowych z udziałem członków Grupy Roboczej ds. Hemostazy Polskiego Towarzystwa Hematologów i Transfuzjologów, które miały miejsce w 2015 r. Adresatem zaleceń są przede wszystkim lekarze sprawujący bezpośrednią opiekę nad chorymi na wrodzone skazy krwotoczne.

\section{Wprowadzenie}

Przyczyną wrodzonych osoczowych skaz krwotocznych jest najczęściej niedobór lub zaburzenie funkcji pojedynczego czynnika krzepnięcia krwi. Aktywność czynników krzepnięcia wyraża się w jednostkach międzynarodowych (international unit; IU). Wyjątkiem jest fibrynogen, który oznacza się w jednostkach wagowych. Za 1 IU danego czynnika krzepnięcia przyjmuje się jego aktywność w $1 \mathrm{ml}$ prawidłowego świeżego osocza, uzyskanego z krwi zmieszanej w stosunku 9:1 z 3,2\% roztworem cytrynianu sodu. U zdrowych osób aktywność większości czynników krzepnięcia mieści się w przedziale 0,5-1,5 IU/ml osocza (50-150 IU/dl albo 50-150\% normy) $[2,3]$.

\section{Definicja}

Hemofilia A to wrodzona skaza krwotoczna spowodowana zmniejszeniem aktywności czynnika krzepnięcia VIII w osoczu.
Hemofilia B to wrodzona skaza krwotoczna spowodowana zmniejszeniem aktywności czynnika IX w osoczu.

\section{Etiologia i patogeneza}

\section{Hemofilia A}

Czynnik VIII jest glikoproteiną syntetyzowaną głównie w hepatocytach, ale także w nerkach, komórkach śródbłonka i tkance limfatycznej [4]. Czynnik VIII jest jednym z największych (2351 aminokwasów, masa cząsteczkowa $293000 \mathrm{Da})$ i najmniej stabilnych czynników krzepnięcia, występującym w krwiobiegu w niekowalencyjnym kompleksie z czynnikiem von Willebranda (Von Willebrand Factor; VWF) [4]. Czynnik von Willebranda chroni FVIII przed przedwczesną proteolityczną degradacją i przenosi go do miejsc uszkodzenia śródbłonka naczyniowego. Czas biologicznego półtrwania FVIII wynosi około $12 \mathrm{~h}$.

Gen czynnika VIII został sklonowany w 1984 r. [5]. Znajduje się on na długim ramieniu chromosomu X (Xq28) i ma wielkość 186000 par zasad (base pair; bp). Niezwykłość genu FVIII (F8) polega na obecności w jego intronie 22 (IVS22) dwóch dodatkowych genów F8A i F8B [6]. F8A jest transkrybowany w odwrotnym kierunku do genu FVIII. Dwie dodatkowe kopie F8A występują poza genem FVIII oddalone o $400 \mathrm{kbp} \mathrm{w}$ kierunku telomeru. Funkcje F8A i F8B nie zostały dotąd poznane.

Najczęściej występującą mutacją u chorych na ciężką hemofilię A (około 45\% przypadków) jest duża inwersja i translokacja eksonów 1-22 (wraz $z$ intronami), w następstwie homologicznej rekombinacji zachodzącej pomiędzy genem F8A w intronie 22 i jedną z kopii F8A znajdującą się poza genem FVIII [7]. Mutacja ta powstaje praktycznie wyłącznie w męskich komórkach rozrodczych [8]. Inne mutacje odpowiedzialne za hemofilię to mutacje punktowe (w 85\% zmiany sensu, a w 15\% nonsensowne), z czego około $5 \%$ to duże lub małe delecje i insercje, a także inwersja w intronie 1 [9]. Wynikiem mutacji jest brak syntezy FVIII, jej zmniejszenie lub synteza nieprawidłowego białka. 


\section{Hemofilia B}

Czynnik IX jest 415-aminokwasową proteazą serynową, syntetyzowaną w wątrobie [10]. Wraz z czynnikami krzepnięcia II, VII i X stanowi grupę czynników zespołu protrombiny, do syntezy których niezbędna jest witamina K. Stężenie FIX w osoczu jest około 50 razy większe niż stężenie FVIII. Czas biologicznego półtrwania FIX wynosi około $24 \mathrm{~h}$.

Gen czynnika IX został sklonowany w 1982 r. [11]. Znajduje się on na długim ramieniu chromosomu X (Xq27), centromerycznie w stosunku do genu FVIII i ma wielkość 34 $000 \mathrm{bp}$. Opisano ponad 3000 neutralnych polimorfizmów i mutacji we wszystkich regionach genu F9 odpowiedzialnych za wystapienie hemofilii $B, z$ których najczęstsze to mutacje punktowe, a w dalszej kolejności mutacje tzw. miejsc splicingowych, przesunięcia ramki odczytu oraz duże delecje/rearanżacje [12, 13]. Podobnie jak w przypadku hemofilii A, wynikiem mutacji w F9 jest brak syntezy FIX, jej zmniejszenie lub synteza nieprawidłowego białka. Najbardziej niezwykłą mutacją w F9 jest mutacja w regionie promotorowym bp -23 do bp +13 , której wynikiem jest hemofilia B Leyden [14]. Ta postać hemofilii B objawia się we wczesnym dzieciństwie całkowitym brakiem FIX, ale w trakcie osobniczego dojrzewania aktywność FIX w osoczu zwiększa się, by w niektórych przypadkach trwale osiągnąć wartość prawidłową. Pojawienie się ekspresji genu w tym przypadku jest prawdopodobnie indukowane przez androgeny lub hormon wzrostu, lecz mechanizm tego zjawiska nie został dotąd wyjaśniony [15, 16].

\section{Sposób dziedziczenia i nosicielstwo}

Tak jak wszystkie cechy zależne od genów sprzężonych z płcią, hemofilia A i B pojawia się głównie u mężczyzn, zaś kobieta przekazująca cechę jest jej nosicielką. Ponieważ $\mathrm{w}$ rodzinie przekazywany jest gen $\mathrm{z}$ tą samą mutacją, mężczyźni dotknięci hemofilią w obrębie jednej rodziny mają tę samą postać hemofilii. Za pewne nosicielki hemofilii uznaje się córki mężczyzn chorych na hemofilię, matki co najmniej dwóch chorych synów oraz matki jednego chorego syna, w których rodzinie inny krewny choruje na hemofilię [17]. Potencjalne nosicielki hemofilii to córki nosicielek hemofilii (w tym siostry mężczyzn chorych na hemofilię) oraz matki jednego chorego syna, w których rodzinie nikt inny nie chorował na hemofilię. Prawdopodobieństwo przekazania przez nosicielkę genu hemofilii dziecku wynosi 0,5, co oznacza, że ryzyko hemofilii u syna oraz ryzyko nosicielstwa tej choroby u córki jest równe 50\%. Ponieważ aktywność FVIII i FIX w osoczu nosicielek wynosi zazwyczaj około $50 \%$ wartości prawidłowej i jest wystarczająca dla prawidłowego przebiegu procesu krzepnięcia krwi, nosicielki rzadko wykazują skłonność do nadmiernych krwawień [17]. Skłonność taka może jednak wystąpić u kobiet dotkniętych skrajną lyonizacją (nieprawidłową inaktywacją chromosomu $\mathrm{X}$ pochodzącego od jednego $\mathrm{z}$ rodziców), $\mathrm{u}$ kobiet $\mathrm{z}$ zespołem Turnera (XO) oraz u córek urodzonych ze związku chorego na hemofilię $z$ nosicielką hemofilii, gdyż $w$ tych przypadkach aktywność niedoborowego czynnika krzepnięcia może być bardzo mała, a nawet nieoznaczalna.

\section{Epidemiologia}

Hemofilia występuje z częstością 1 na 10000 urodzeń [18]. Szacuje się, że 80-85\% wszystkich chorych na hemofilię choruje na hemofilię A, a jedynie $15-20 \%$ na hemofilię B. Według danych Światowej Federacji Hemofilii (World Federation of Haemophilia; WFH) opublikowanych w 2010 r., liczba chorych na hemofilię na świecie wynosi około 400000 [19]. Częstość występowania hemofilii A i B w Polsce została oszacowana na 1:12 300 mieszkańców [20]. U około 30-50\% polskich chorych mutacja występuje spontanicznie, a wywiad rodzinny jest negatywny [20].

\section{Klasyfikacja i obraz kliniczny}

Krwawienia w hemofilii A i B są następstwem upośledzenia wtórnej hemostazy. Procesy pierwotnej hemostazy przebiegają prawidłowo, ale płytkowy czop hemostatyczny nie jest dostatecznie wzmocniony włóknikiem (fibryną), albowiem w następstwie niedoboru FVIII lub FIX nie jest wytwarzana dostateczna ilość trombiny przekształcającej fibrynogen w fibrynę. Skrzep o słabej strukturze ulega łatwo rozpadowi, co objawia się skłonnością do nadmiernych krwawień. Rozpoznanie obu typów hemofilii opiera się na pomiarze aktywności niedoborowego czynnika krzepnięcia w osoczu. Nasilenie krwawień zależy od stopnia niedoboru FVIII lub FIX. Wyróżnia się 3 postacie każdej z hemofilii: ciężką, umiarkowaną i łagodną $[3,21]$ (Tab. I).

Ostatnio ukazały się doniesienia sugerujące, że przebieg kliniczny ciężkiej hemofilii $\mathrm{B}$ może być łagodniejszy w porównaniu z ciężką hemofilią A [22, 23]. Obserwacje te zostały jednak podważone przez innych ekspertów, którzy albo nie zauważali istotnych różnic $\mathrm{w}$ nasileniu objawów skazy krwotocznej między hemofilią A i B, albo wręcz dostrzegli cięższy przebieg kliniczny u pacjentów $\mathrm{z}$ hemofilią B [24-26].

\section{Objawy ciężkiej hemofilii}

Dzieci rodzą się pozornie zdrowe i zwykle nie krwawią przy odpadaniu kikuta pępowiny. Przedłużone i obfite krwawienia występują przy zabiegu obrzezania. Skaza krwotoczna ujawnia się na ogół na przełomie 1. i 2. r.ż. pod postacią wylewów krwi podskórnych i domięśniowych oraz przedłużonych krwawień po skaleczeniu języka lub wargi [27-29].

Wylewy krwi do stawów - zazwyczaj zaczynają pojawiać się w wieku 2-3 lat. Najczęściej umiejscawiają się w stawach kolanowych, łokciowych i skokowo-goleniowych i są wynikiem niewielkich urazów. Potem dominują krwawienia samoistne. Powtarzające się krwawienia do stawów są przyczyną ich postępującego zwyrodnienia [30, 31].

Krwawienia do stawów są najbardziej charakterystycznym objawem ciężkiej hemofilii. Krwawieniu towarzyszy najpierw „aura” w postaci uczucia drętwienia lub mrowienia, następnie ból, obrzęk, wzmożone ocieplenie skóry nad zajętym stawem i ograniczenie jego ruchomości. „Oszczędzanie” kończyny może być jedynym objawem krwawienia do stawu u najmniejszych dzieci. 
Tabela I - Klasyfikacja hemofilii A i B

Table I - Classification of haemophilia A and B

\begin{tabular}{lcl}
\hline Aktywność czynnika VIII lub czynnika IX & Postać hemofilii & \multicolumn{1}{c}{ Główne objawy } \\
\hline $\begin{array}{l}<0,01 \mathrm{IU} / \mathrm{ml} \\
(<1 \mathrm{IU} / \mathrm{dl} \text { albo }<1 \% \text { normy) }\end{array}$ & ciężka & $\begin{array}{l}\text { Samoistne krwawienia do stawów i mięśni; nadmierne } \\
\text { krwawienia po urazach, ekstrakcjach zębów, zabiegach } \\
\text { chirurgicznych }\end{array}$ \\
$0,01-0,05 \mathrm{IU} / \mathrm{ml}$ & umiarkowana & $\begin{array}{l}\text { Krwawienia do stawów i mięśni po niewielkich urazach, } \\
\text { rzadko samoistne; nadmierne krwawienia po urazach, } \\
\text { ekstrakcjach zębów, zabiegach chirurgicznych }\end{array}$ \\
$>0,05 \leq 0,40 \mathrm{IU} / \mathrm{ml}$ & & $\begin{array}{l}\text { Praktycznie nie obserwuje się samoistnych krwawień do } \\
\text { stawów i mięśni; nadmierne krwawienia po urazach, } \\
(>5 \leq 40 \mathrm{IU} / \mathrm{dl} \text { albo }\end{array}$ \\
$>5 \leq 40 \%$ normy) & łagodna & ekstrakcjach zębów, zabiegach chirurgicznych \\
\hline IU (international unit) - jednostka międzynarodowa & & \\
\hline
\end{tabular}

Pod pojęciem stawu docelowego (target joint) należy rozumieć staw, w którym doszło do co najmniej 3 samoistnych krwawień w okresie 3-6 miesięcy. Jeżeli w takim stawie nie obserwuje się krwawień w okresie kolejnych 12 miesięcy, to nie jest on już uważany za staw docelowy [32, 33].

Krwawienia do mięśni - samoistne bądź pourazowe, najczęściej lokalizują się w goleniach, udach, pośladkach, przedramionach oraz w mięśniu biodrowo-lędźwiowym [18]. Bardzo często powstały krwiak uciska na naczynia krwionośne i nerwy. Wynikiem źle leczonych krwawień do mięśni może być np. niedokrwienny przykurcz Volkmanna następstwo krwiaka w grupie mięśni zginaczy przedramienia, porażenie nerwu biodrowego w następstwie wylewu krwi do mięśnia biodrowo-lędźwiowego oraz stopa końska po uszkodzeniu nerwu strzałkowego tylnego przez krwiak zlokalizowany w mięśniu brzuchatym łydki. Zaotrzewnowe wylewy do prawego mięśnia biodrowo-lędźwiowego mogą być mylnie rozpoznane jako zapalenie wyrostka robaczkowego.

Krwiaki tylnej ściany gardła i dna jamy ustnej - mogą uciskać na drogi oddechowe. Szybkie rozpoczęcie leczenia zapobiega konieczności intubacji lub tracheostomii.

Krwiomocz - może być wywołany kamicą układu moczowego. Nierzadko towarzyszy mu ból w okolicy lędźwiowej. W przypadku dużego nasilenia może prowadzić do istotnej klinicznie niedokrwistości.

Krwawienie $\mathbf{z}$ górnego odcinka przewodu pokarmowego - najczęściej związane z chorobą wrzodową żołądka lub dwunastnicy bądź z zapaleniem krwotocznym błony śluzowej żołądka. U pacjentów $\mathrm{z}$ wieloletnim zakażeniem wirusem zapalenia wątroby typu C (hepatitis C viralis; HCV) i typu B (hepatitis B viralis; HBV) źródłem krwawienia mogą być żylaki przełyku lub dna żołądka wywołane nadciśnieniem w układzie żyły wrotnej w przebiegu pozapalnej marskości wątroby [34].

Krwawienie śródczaszkowe - występuje u około 5\% chorych i jest obarczone dużą śmiertelnością, zajmując jedno $\mathrm{z}$ pierwszych miejsc wśród przyczyn zgonów chorych na ciężką hemofilię [35, 36].

Krwawienie po usunięciu stałego zęba lub migdałków i krwawienia z ran operacyjnych u pacjentów, którzy nie otrzymali odpowiedniego leczenia hemostatycznego - często bardzo obfite, mogą pojawić się po upływie kilku godzin od zabiegu i nieleczone prowadzą do wykrwawienia pacjenta.

\section{Objawy kliniczne umiarkowanej hemofilii}

Wylewy krwi do stawów - są mniej częste niż w ciężkiej hemofilii i zazwyczaj występują w następstwie urazów. Dotyczą zwykle jednego lub dwóch stawów i rzadko prowadzą do ich zwyrodnienia.

Krwawienia do mięśni - występują bardzo rzadko.

Krwawienia pourazowe - zamknięte i otwarte są tak samo niebezpieczne jak w ciężkiej hemofilii.

\section{Objawy kliniczne łagodnej hemofilii}

Praktycznie nie występują krwawienia do stawów i mięśni [18]. Pacjenci z aktywnością FVIII/FIX powyżej 25\% normy zazwyczaj prowadzą normalny tryb życia, nie wiedząc o istnieniu skazy, która może ujawnić się dopiero w trakcie operacji chirurgicznej lub w następstwie urazu.

\section{Diagnostyka laboratoryjna}

W przypadku podejrzenia skazy krwotocznej początkowo wykonuje się testy przesiewowe hemostazy, które obejmują oznaczenie:

a) liczby płytek krwi,

b) czasu okluzji (Closure Time; CT) w urządzeniu PFA-100 lub PFA-200 (Platelet Function Analyzer, Siemens),

c) czasu protrombinowego (Prothrombin Time; PT),

d) czasu częściowej tromboplastyny po aktywacji (Activated Partial Thrombplastin Time; APTT),

e) stężenia fibrynogenu i ewentualnie czasu trombinowego (thrombin time; TT).

W tabeli II zestawiono wyniki badań przesiewowych hemostazy w wybranych skazach krwotocznych. Należy podkreślić, że w przypadku aktywności FVIII lub FIX >30 IU/dl (czyli obejmującej rozpoznanie łagodnej hemofilii A lub B), APTT często pozostaje w granicach normy. Niezbędnym warunkiem ostatecznego rozpoznania hemofilii jest wykazanie w testach laboratoryjnych zmniejszonej aktywności FVIII lub FIX w osoczu [37]. U noworodków fizjologicznie aktywność FIX jest zmniejszona, a APTT przedłużony [38]. Jeśli jednak aktywność FIX wynosi <1 IU/dl, rozpoznanie ciężkiej hemofilii B jest pewne. U zdrowego noworodka aktywność FVIII jest porównywalna $\mathrm{z}$ aktywnością FVIII u zdrowego dorosłego. 
Tabela II - Badania przesiewowe hemostazy w wybranych skazach krwotocznych

Table II - Laboratory screening of haemostasis in selected bleeding disorders

\begin{tabular}{lccccc}
\hline Status pacjenta & Liczba płytek krwi & Czas okluzji w PFA & PT & APTT & Stężenie fibrynogenu/TT \\
\hline Osoba zdrowa & $\mathrm{N}$ & $\mathrm{N}$ & $\mathrm{N}$ & $\mathrm{N}$ & \\
Hemofilia A lub B & $\mathrm{N}$ & $\mathrm{N}$ & $\mathrm{N}$ & $\uparrow$ lub N & $\mathrm{N} / \mathrm{N}$ \\
VWD typ 1, 2 (z wyjątkiem 2N), 3 & $\mathrm{N}$ lub $\downarrow$ & $\mathrm{N}$ lub $\uparrow$ & $\mathrm{N}$ & $\mathrm{N}$ lub $\uparrow$ & $\mathrm{N} / \mathrm{N}$ \\
VWD typ 2N & $\mathrm{N}$ & $\mathrm{N}$ & $\mathrm{N}$ & $\uparrow$ lub N & $\mathrm{N} / \mathrm{N}$ \\
Trombocytopatia & $\mathrm{N}$ lub $\downarrow$ & $\mathrm{N}$ lub $\uparrow$ & $\mathrm{N}$ & $\mathrm{N}$ & $\mathrm{N} / \mathrm{N}$ \\
\hline
\end{tabular}

Jeśli aktywność FVIII i FIX jest większa niż 30 IU/dl, APTT może pozostawać w zakresie wartości prawidłowych;

Testem różnicującym $\mathrm{z}$ hemofilią A jest test wiązania FVIII z czynnikiem von Willebranda (zmniejszone wiązanie w VWD typ 2N i prawidłowe w hemofilii A); N - wartość prawidłowa; - czas przedłużony; $\downarrow$ - wartość zmniejszona; VWD (von Willebrand disease) - choroba von Willebranda; PFA - Platelet Function Analyzer (Siemens); PT (prothrombin time) - czas protrombinowy; APTT (activated partial thromboplastin time) - czas częściowej tromboplastyny po aktywacji; TT (thrombin time) - czas trombinowy

Do oznaczeń koagulacyjnej aktywności FVIII (FVIII coagulation activity; FVIII:C) i FIX (FIX:C) wykorzystuje się metodę jednostopniową koagulacyjną opartą na pomiarze APTT lub rzadziej dwustopniową, z wykorzystaniem substratu chromogennego [39, 40]. Oznaczeń FVIII:C i FIX:C dokonuje się nie tylko w celu ustalenia rozpoznania, ale także monitorowania leczenia substytucyjnego [41]. Należy zaznaczyć, że aktywność FVIII/FIX u chorych na ciężką i umiarkowaną hemofilię pozostaje na tym samym poziomie przez całe życie (wyjątkiem jest hemofilia B Leyden). W przypadku łagodnej hemofilii A, tak jak u osób zdrowych, stwierdza się krótkotrwałe zwiększenie aktywności FVIII po wysiłku fizycznym, w zakażeniach, w warunkach stresu, po wstrzyknięciu adrenaliny lub 1-deamino-8-D-argininowazopresyny (DDAVP). Obecnie przeważa pogląd, że proces diagnostyczny hemofilii A i B powinien obejmować zarówno określenie stopnia niedoboru FVIII lub FIX w osoczu, jak i identyfikację mutacji sprawczej $[42,43]$.

$\mathrm{U}$ pewnych i potencjalnych nosicielek hemofilii należy zawsze oznaczyć FVIII:C lub FIX:C. Prawidłowe aktywności tych czynników krzepnięcia nie wykluczają nosicielstwa. Prawdopodobieństwo nosicielstwa hemofilii A można w przybliżeniu oszacować, porównując aktywność czynnika VIII z zawartością antygenu czynnika von Willebranda (von Willebrand factor antigen, VWF:Ag) w osoczu. Jeżeli stosunek FVIII:C/VWF:Ag jest mniejszy niż 0,7, prawdopodobieństwo nosicielstwa wynosi 80\% [44]. Niemniej jednak uważa się, że każda potencjalna nosicielka hemofilii powinna mieć możliwość wykonania badań genetycznych, które zwiększają szansę wykrycia stanu nosicielstwa do ponad 95\% [45-49].

\section{Ustalenie rozpoznania i diagnostyka różnicowa}

Rozpoznanie ustala się na podstawie objawów klinicznych, dokładnie zebranego wywiadu rodzinnego oraz wyników badań laboratoryjnych [50]. Prawidłowy czas okluzji w urządzeniu PFA i prawidłowa aktywność VWF, a także odmienny sposób dziedziczenia odróżniają hemofilię A od choroby von Willebranda (von Willebrand disease; VWD). W celu odróżnienia hemofilii A od VWD typ 2N konieczne jest przeprowadzenie testu wiązania VWF z FVIII (zaburzone w VWD typ 2N), albowiem poza tą różnicą wyniki innych testów krzepnięcia mogą być identyczne w obu jednostkach chorobowych.
U części pacjentów, z potwierdzonym testami genetycznymi rozpoznaniem umiarkowanej lub łagodnej hemofilii A, stwierdza się istotne rozbieżności w wynikach oznaczeń FVIII:C metodą koagulacyjną jednostopniową i chromogenną [51-53]. Niekiedy wynik oznaczenia FVIII metodą koagulacyjną pozostaje w granicach wartości prawidłowych i dopiero wykonanie oznaczenia metodą chromogenną pozwala rozpoznać łagodną lub umiarkowaną hemofilię A.

\section{Wytyczne rozpoznawania hemofilii A i B}

1. Każdy pacjent $\mathrm{z}$ objawami klinicznymi mogącymi odpowiadać hemofilii, każdy noworodek z rodziny, w której występuje lub występowała hemofilia, a także każdy pacjent, a zwłaszcza noworodek lub dziecko $z$ istotnymi odchyleniami od normy w testach przesiewowych hemostazy, powinni zostać skierowani do ośrodka medycznego zajmującego się diagnostyką i leczeniem wrodzonych skaz krwotocznych.

2. Wykazanie zmniejszonej aktywności czynnika VIII lub czynnika IX w osoczu jest niezbędnym warunkiem rozpoznania hemofilii A lub B.

3. W okresie noworodkowym APTT jest przedłużone, a aktywność czynnika IX zmniejszona w porównaniu $z$ osobami dorosłymi. Dlatego rozpoznanie hemofilii B u noworodka jest uprawnione wyłącznie przy stwierdzeniu aktywności czynnika IX poniżej 1IU/dl. Jeśli FIX:C jest większa niż 1IU/dl, ale mniejsza niż 50IU/dl, oznaczenie FIX:C należy powtórzyć po ukończeniu przez dziecko 6. miesiąca życia.

4. Aktywność czynnika VIII w okresie noworodkowym jest porównywalna $\mathrm{z}$ aktywnością czynnika VIII u osób dorosłych. Rozpoznanie hemofilii A u noworodka ze zmniejszona aktywnością czynnika VIII jest zatem w pełni uprawnione.

5. Oznaczeń aktywności czynników VIII i IX w osoczu najczęściej dokonuje się metodą jednostopniową koagulacyjną, znacznie rzadziej - dwustopniową $\mathrm{z}$ użyciem substratu chromogennego. W przypadku łagodnej i umiarkowanej hemofilii A oznaczenie metodą chromogenną może być bardziej wiarygodne (lepsza korelacja z nasileniem skazy krwotocznej) 
niż oznaczenie metodą koagulacyjną jednostopniową.

6. U pacjentów $\mathrm{z}$ podejrzeniem hemofilii A i prawidłowym wynikiem FVIII:C w teście koagulacyjnym jednostopniowym należy wykonać oznaczenie z zastosowaniem substratu chromogennego, albowiem u części pacjentów z łagodną i umiarkowaną hemofilią A obserwuje się istotne rozbieżności w wynikach oznaczeń obiema metodami.

7. W przypadku stwierdzenia zmniejszonej aktywności czynnika VIII przy negatywnym wywiadzie rodzinnym hemofilii A należy oznaczyć aktywność czynnika von Willebranda, zawartość antygenu czynnika von Willebranda oraz przeprowadzić test wiązania czynnika VIII z VWF. W przypadku VWD typu 2N (dziedziczenie autosomalne) stwierdza się zmniejszoną aktywność FVIII i zaburzone wiązanie FVIII $z$ VWF.

8. W miarę możliwości należy dążyć do określenia mutacji odpowiedzialnej za wystąpienie hemofilii A i hemofilii B.

Wytyczne rozpoznawania nosicielstwa hemofilii A i B i wykonywania badań prenatalnych

1. Każda kobieta, w której rodzinie występuje hemofilia, powinna mieć możliwość uzyskania porady genetycznej. Ryzyko nosicielstwa genu hemofilii należy wstępnie określić na podstawie analizy rodowodu. Pacjentce należy udzielić wyczerpujących informacji co do ryzyka nosicielstwa, możliwości diagnostycznych nosicielstwa, jak również ryzyka przekazania choroby potomstwu.

2. Pewne i potencjalne nosicielki hemofilii należy poddać badaniu aktywności FVIII lub FIX w osoczu. W przypadku obniżenia aktywności FVIII lub FIX należy stosować zalecenia postępowania i leczenia właściwe dla odpowiedniej postaci hemofilii.

3. W miarę możliwości, u każdej potencjalnej i pewnej nosicielki hemofilii należy przeprowadzić badania genetyczne w celu określenia mutacji sprawczej hemofilii.

4. W miarę możliwości każda nosicielka hemofilii w ciąży powinna mieć wykonane badania prenatalne. Jednakże potencjalnym nosicielkom należy przede wszystkim zalecać wykonanie badań genetycznych przed planowaną ciążą, aby uniknąć inwazyjnych badań prenatalnych u tych kobiet, u których nosicielstwo zostanie wykluczone.

5. Zaleca się, aby w każdym przypadku określić płeć dziecka na postawie badania ultrasonograficznego wykonanego $\geq 15$. tygodnia ciąży lub - o ile to możliwe - wykrywając DNA płodu we krwi matki (free foetal DNA; ffDNA) metodą RT-PCR już około 7.9 tygodnia ciąży (trafność diagnozy sięga 98-99\% po 16. tygodniu ciąży).
6. W uzasadnionych przypadkach możliwa jest inwazyjna diagnostyka prenatalna hemofilii, obejmująca: biopsję trofoblastu (metoda z wyboru), którą można wykonać w 11.-14. tygodnia ciąży, amniopunkcję ( $>15$. tygodnia ciąży) i kordocentezę ( $>18$. tygodnia ciąży). Ryzyko poronienia związane z inwazyjnymi metodami diagnostyki prenatalnej szacuje się na 0,5-2\% (w przypadku kordocentezy nawet do 6\%). Istnieje także metoda oparta na reakcji PCR - określana jako digital relative mutation dosage, oceniająca różnicę stężeń zmutowanego oraz prawidłowego allelu w osoczu kobiety i pozwalająca na stwierdzenie, czy płód jest chory na hemofilię. Uzyskanie wyniku jest możliwe już od 11. tygodnia ciąży. Stężenie płodowego DNA we krwi matki jest największe w III trymestrze ciąży, stąd metoda ta jest bardzo dobrą alternatywą również dla kordocentezy.

7. Opiekę nad nosicielką hemofilii A w ciąży powinien sprawować zespół doświadczonych klinicystów złożony $\mathrm{z}$ ginekologa, hematologa $\mathrm{i}$ jeśli zachodzi potrzeba - genetyka.

\section{Terapia genowa}

Badania nad terapią genową hemofilii A i B są prowadzone od ponad dwóch dekad. W ostatnim czasie doniesiono o częściowym powodzeniu terapii genowej u 10 chorych na ciężką hemofilię B, u których uzyskano kilkuprocentowy wzrost aktywności czynnika IX w osoczu, utrzymujący się przez ponad 3 lata od dożylnego wstrzyknięcia ludzkiego genu F9 z zastosowaniem wektora wirusowego (wirus adenopodobny serotypu 8, adeno-associated virus-8; AAV-8) [54, 55]. Jednak pomimo tego sukcesu należy stwierdzić, że hemofilia jest wciąż chorobą nieuleczalną, albowiem „przekształcenie" hemofilii ciężkiej w umiarkowaną, a nawet łagodną nie wyeliminuje całkowicie skłonności do nadmiernych krwawień. Co więcej, terapia genowa hemofilii A wciąż nie wyszła $z$ wstępnej fazy badań klinicznych, a przyczyną tego opóźnienia w stosunku do hemofilii B jest znaczna wielkość genu kodującego FVIII, wyraźnie utrudniająca przeprowadzenie manipulacji genetycznych, przede wszystkim „upakowania” F8 w jednym z dostępnych w chwili obecnej wektorów wirusowych [56].

\section{Leki hamujące krwawienia w hemofilii}

Podstawą leczenia ciężkiej hemofilii pozostaje zatem stosowanie koncentratów niedoborowych czynników krzepnięcia krwi (terapia substytucyjna). Koncentraty te podaje się w celu zahamowania aktywnego krwawienia (leczenie „na żądanie”) albo w celu prewencji występowania krwawień (profilaktyka) [18]. W leczeniu hemofilii stosuje się także desmopresynę i różne leki wspomagające, które, co prawda, nie zwiększają aktywności niedoborowego czynnika krzepnięcia w osoczu, ale wpływają korzystnie na hemostazę w innych mechanizmach. Poniżej wymieniono, a następnie 
scharakteryzowano leki hemostatyczne stosowane u chorych na hemofilię:

a) koncentraty FVIII i FIX wytwarzane z ludzkiego osocza (osoczopochodne czynniki krzepnięcia),

b) koncentraty FVIII i FIX wytwarzane metodami inżynierii genetycznej (rekombinowane czynniki krzepnięcia),

c) koncentraty FVIII i FIX o przedłużonym czasie biologicznego półtrwania (extended half-life; EHL),

d) 1-deamino-8-D-arginino wazopresyna (DDAVP), czyli desmopresyna,

e) leki wspomagające: kwas traneksamowy (tranexamic acid; TXA) i miejscowe środki hemostatyczne.

\section{Koncentraty osoczopochodnych (plasma derived; $p d)$ czynników VIII(pdFVIII) i IX (pdFIX)}

Osoczopochodne koncentraty FVIII/FIX są wytwarzane z puli osocza pobranego od tysięcy dawców. W toku produkcji są oczyszczane z domieszek różnych białek za pomocą chromatografii, a od 1986 r. obowiązkowo poddawane procedurom inaktywacji lub eliminacji wirusów [57-62]. W zależności od zastosowanej technologii wytwarzania, koncentraty pdFVIII zawierają czynnik von Willebranda lub są go pozbawione. Przed powszechnym wprowadzeniem procedur inaktywujących wirusy w 1986 r., koncentraty pdFVIII i pdFIX były źródłem zakażenia wirusami zapalenia wątroby HBV i HCV oraz ludzkim wirusem niedoboru odporności (human immunodeficiency virus; HIV) [63, 64]. Obecnie bezpieczeństwo stosowania leków osoczopochodnych jest oceniane jako wysokie, przede wszystkim wskutek wprowadzenia: 1) starannej selekcji dawców (wykluczanie dawców „podwyższonego ryzyka"), 2) wysokiej jakości testów skryningowych na obecność cząstek zakaźnych w donacjach (nucleic acid testing; NAT), 3) skutecznych procedur inaktywacji/eliminacji wirusów. Współcześnie zaleca się stosowanie co najmniej dwóch metod inaktywacji/eliminacji wirusów w toku wytwarzania koncentratów czynników krzepnięcia krwi. Najczęściej stosuje się procedury wykorzystujące wysoką temperaturę (heat treatment) oraz organiczny rozpuszczalnik i detergent (solvent/detergent; SD).

Mimo to, po 1986 r. w koncentratach osoczopochodnych wykrywano wirusy bez otoczki lipidowej, np. wirus zapalenia wątroby typu A (hepatitis A viralis; HAV) oraz parvowirus B19 (B19), które trudniej poddają się procedurom niszczącym cząstki zakaźne $[65,66]$. W celu eliminacji B19 sięga się po nano(ultra)filtrację, ale trzeba podkreślić, że metoda ta nie daje pełnej gwarancji pozbycia się wirusa $[67,68]$. Ponadto, ze stosowaniem produktów osoczopochodnych wiąże się ryzyko przeniesienia prionów odpowiedzialnych za wariant choroby Creutzfeldta i Jakoba (variant Creutzfeldt-Jakob disease; vCJD). Niestety wciąż nie są dostępne ani testy laboratoryjne pozwalające wykryć priony ani metody ich eliminacji/inaktywacji [67].

W leczeniu hemofilii B wykorzystywano w przeszłości także koncentraty zespołu protrombiny (prothrombin complex concentrate; PCC), które zawierają czynniki krzepnięcia zależne od witaminy $\mathrm{K}$ (IX, II, VII i X). Obecnie nie zaleca się stosowania PCC u pacjentów z hemofilią B, z powodu ryzyka wystąpienia powikłań zakrzepowo-zatorowych, na które narażeni są pacjenci $z$ hemofilią $B$ otrzymujący duże dawki
PCC powtarzane w krótkich odstępach czasowych, np. w czasie leczenia krwawień zagrażających życiu albo w osłonie operacji chirurgicznych [60]. Innymi czynnikami ryzyka wystąpienia powikłań zakrzepowo-zatorowych u pacjentów z hemofilią B otrzymujących PCC jest pozytywny wywiad zakrzepowo-zatorowy, przewlekłe choroby wątroby, równoczesne stosowanie leków o potencjale trombogennym (np. leki antyfibrynolityczne) oraz stany kliniczne związane z występowaniem powikłań zakrzepowo-zatorowych (np. operacje chirurgiczne, sepsa).

\section{Koncentraty rekombinowanych (recombinant; r) czynników VIII (rFVIII) i IX (rFIX)}

Koncentraty rFVIII i rFIX są wytwarzane przez komórki ssaków, do których wprowadzono gen odpowiedniego czynnika krzepnięcia [60, 62, 69]. Uwalniany do podłoża hodowlanego rFVIII lub rFIX oczyszcza się metodami chromatografii immunopowinowactwa i stabilizuje za pomocą odpowiednich związków białkowych lub cukrowych. Koncentraty rekombinowanych czynników krzepnięcia ostatniej, czyli 3., generacji nie zawierają w podłożu hodowlanym żadnych białek pochodzenia ludzkiego ani zwierzęcego, a do ich stabilizacji nie używa się ludzkiej albuminy. Koncentraty rFVIII nie zawierają czynnika von Willebranda. Rekombinowane czynniki krzepnięcia także poddaje się $\mathrm{w}$ toku produkcji procedurom inaktywacji wirusów. Jak dotąd nie zanotowano żadnego przypadku przeniesienia cząstek zakaźnych przez koncentraty rFVIII lub rFIX [62]. Dane z piśmiennictwa wskazują na podobną skuteczność koncentratów osoczopochodnych i rekombinowanych czynników krzepnięcia VIII i IX w profilaktyce i hamowaniu krwawień w hemofilii [70-74].

Jednym z potencjalnych czynników ryzyka wytworzenia alloprzeciwciał wobec niedoborowego czynnika krzepnięcia, czyli inhibitora FVIII lub FIX, jest typ koncentratu czynnika krzepnięcia. Jednak w dotychczasowych badaniach nie udowodniono w sposób jednoznaczny, by rekombinowane czynniki krzepnięcia były bardziej lub mniej immunogenne od czynników osoczopochodnych. Co prawda, trzy grupy badaczy, niezależnie od siebie, doniosły ostatnio o zwiększonym ryzyku wytworzenia inhibitora upoprzednio nieleczonych pacjentów (previously untreated patients; PUPs) stosujących jeden z koncentratów rFVIII II generacji, ale eksperci nie są całkowicie zgodni co do interpretacji uzyskanych wyników i mają zastrzeżenia co do metod zastosowanych w tych badaniach [75-81]. Co więcej, inna grupa badaczy, analizując dane rejestru EUHASS, doniosła o braku związku konkretnego koncentratu czynnika VIII ze zwiększonym ryzykiem powstawania inhibitora FVIII zarówno u PUPs, jak i PTPs (previously treated patients - pacjenci poprzednio leczeni) [82]. Środowisko zajmujące się leczeniem chorych na hemofilię oczekuje na pełnotekstową publikację wyników badania SIPPET, którego celem było porównanie częstości pojawiania się inhibitora FVIII w grupie chorych na ciężką hemofilię A leczonych rFVIII vs pdFVIII [83]. W planowanym przez Grupę ds. Hemostazy odrębnym artykule (Zasady postępowania $w$ hemofilii A i B powikłanej inhibitorem czynnika VIII i IX [zaktualizowane])) towarzyszącym obecnej pracy, zostaną precyzyjnie omówione m.in. czynniki ryzyka powstawania inhibitora FVIII i FIX. 


\section{Właściwości farmakokinetyczne czynników krzepnięcia}

Po wstrzyknięciu czynnika VIII choremu na hemofilię A obserwuje się najpierw szybki wzrost aktywności FVIII w osoczu (tzw. szczyt, peak), a następnie jej zmniejszanie, przy czym tempo tego zmniejszania (podobnie jak wartość szczytu) jest różna u różnych pacjentów [84]. Proces zmniejszenia aktywności FVIII po osiągnięciu szczytu ma charakter dwufazowy (two-compartmental), co oznacza, że najpierw obserwuje się szybki, ale krótkotrwały spadek aktywności FVIII, po czym dalszy spadek aktywności FVIII jest już znacznie wolniejszy. Ten krótkotrwały, szybki spadek aktywności FVIII zależy głownie od dystrybucji FVIII w organizmie, zaś następujący po nim - dłużej trwający, ale powolny spadek aktywności FVIII zależy przede wszystkim od procesu eliminacji FVIII z organizmu [85]. W porównaniu z FVIII u pacjenta z hemofilią A, FIX u chorego na hemofilię B charakteryzuje jeszcze bardziej złożona farmakokinetyka, z dwiema, a nawet trzema fazami zaniku aktywności FIX w krwiobiegu [86].

Do najważniejszych parametrów farmakokinetycznych (pharmacokinetics; PK) czynników krzepnięcia, których znajomość służy optymalnemu leczeniu chorych, należy zaliczyć:

1. Końcowy okres półtrwania (terminal half-life; $\mathrm{T} 1 / 2$ ) (h);

2. $\mathrm{C}_{\max }$, czyli maksymalną aktywność (IU/ml lub IU/dl) czynnika krzepnięcia, zwykle oznaczaną w próbce osocza pacjenta pobranego 15-30 min po wstrzyknięciu czynnika;

3. Odzysk in vivo (incremental in vivo recovery; IVR), który wylicza się ze wzoru:

$$
\begin{aligned}
\mathrm{IVR}= & {\left[\mathrm{C}_{\max }(\mathrm{IU} / \mathrm{dl})-\mathrm{C}_{\text {przed podaniem leku }}(\mathrm{IU} / \mathrm{dl})\right] } \\
& : \text { dawka czynnika }(\mathrm{IU} / \mathrm{kg})
\end{aligned}
$$

Zwykle $\mathrm{C}_{\max }$ określa się $\mathrm{w}$ próbce osocza pobranego 15-30 min po podaniu czynnika krzepnięcia. Np. jeśli podano $50 \mathrm{IU} / \mathrm{kg}$ FVIII pacjentowi z wyjściową aktywnością FVIII $0 \mathrm{IU} / \mathrm{dl}$, a $\mathrm{C}_{\max }$ wyniósł $100 \mathrm{IU} / \mathrm{dl}$, to IVR = 2 [(100 $\mathrm{IU} / \mathrm{dl}-0 \mathrm{IU} / \mathrm{dl}): 50 \mathrm{IU} / \mathrm{kg}]$.

4. Klirens (ml/h/kg) - objętość osocza, z której stosowany lek (czynnik krzepnięcia) uległ eliminacji w jednostce czasu w przeliczeniu na kg masy ciała.

Wartość odzysku in vivo jest potrzebna do przewidywania maksymalnej aktywności czynnika krzepnięcia po jego dożylnym wstrzyknięciu [87]. Ta wartość ma duże znaczenie np. u pacjenta przygotowywanego do operacji chirurgicznej $\left(\mathrm{C}_{\max }\right.$ musi uzyskać odpowiednią wartość bezpośrednio przed operacją) albo u chorego, który musi otrzymać odpowiednią dawkę leku $\mathrm{z}$ powodu krwawienia do stawu ( $\mathrm{C}_{\max }$ musi osiągnąć odpowiednią wartość, aby skutecznie zatrzymać krwawienie). Z kolei wartości końcowego okresu półtrwania i klirensu są niezbędne dla planowania terapii, w której ważne jest nie tyle, jaka będzie maksymalna aktywność czynnika krzepnięcia w osoczu, ale - w jakim czasie od wstrzyknięcia czynnika należy się spodziewać spadku jego aktywności w osoczu. Dzięki znajomości wartości $\mathrm{T} \quad 1 / 2$ i klirensu można optymalnie zaplanować dawkowanie czynnika w ramach profilaktyki, zarówno krótkoterminowej (np. w okresie okołooperacyjnym), jak i długoterminowej [88].

Inne ważne parametry farmakokinetyczne czynników krzepnięcia, jednak odgrywające mniejszą rolę przy podejmowaniu decyzji klinicznych od wcześniej omówionych, to: średni czas obecności leku (mean residence time; MRT), objętość dystrybucji (volume of distribution), którą albo wylicza się na podstawie końcowego okresu półtrwania i masy ciała $\left(\mathrm{V}_{\mathrm{z}} / \mathrm{kg}\right)$, albo odnosi do stanu wysycenia (steady state) $\left(\mathrm{V}_{\mathrm{ss}} / \mathrm{kg}\right)$, oraz pole pod krzywą (area under the curve; AUC) - liczone od chwili podania leku do ostatniego, wykrywalnego w osoczu stężenia badanego czynnika krzepnięcia.

Należy podkreślić, że parametry PK zależą nie tylko od stosowanego leku, ale także od indywidualnych cech pacjenta. Niekiedy, między pacjentami w tym samym wieku, z tym samym rozpoznaniem, o zbliżonej masie ciała i leczonych tym samym lekiem obserwuje się nawet kilkukrotne (sic!) różnice w wartościach końcowego okresu półtrwania i klirensu [89]. Dlatego indywidualizacja (albo personalizacja) terapii substytucyjnej $\mathrm{w}$ hemofilii jest obecnie jedną $\mathrm{z}$ największych potrzeb, ale także jednym z większych wyzwań dla środowiska badawczego zajmującego się leczeniem chorych na hemofilię $[90,91]$.

\section{Dawkowanie osoczopochodnych i rekombinowanych FVIII i FIX}

W tabeli III przedstawiono sugerowaną docelową aktywność FVIII i FIX w osoczu pacjentów z hemofilią A i B w wybranych sytuacjach klinicznych. Ponieważ dożylne wstrzyknięcie 1 IU FVIII na $1 \mathrm{~kg}$ mc. powoduje wzrost aktywności FVIII w osoczu biorcy przeciętnie o 2IU/dl, do obliczenia należnej dawki FVIII stosuje się następujący wzór [92-96]:

Dawka (IU) = pożądane zwiększenie aktywności FVIII w osoczu biorcy (\%) x masa ciała $(\mathrm{kg})$ x 0,5

Ponieważ IVR czynnika VIII, zarówno osoczopochodnego, jak i rekombinowanego, wynosi przeciętnie około 2 IU/kg/IU/ dl, więc powyższy wzór obowiązuje zarówno dla pdFVIII, jak i rFVIII [97]. Częstotliwość dawek wynika z okresu półtrwania FVIII. Dlatego, zależnie od sytuacji klinicznej i wynikającej z niej konieczności utrzymywania określonej aktywności FVIII w osoczu, wstrzyknięcia powtarza się co 8, 12 lub 24 h, odpowiednio modyfikując kolejne dawki czynnika. Warto $\mathrm{w}$ tym miejscu dodać, że $\mathrm{T} 1 / 2$ FVIII $\mathrm{u}$ dzieci $\mathrm{z}$ hemofilią A jest krótszy (około 8-9 h), a klirens istotnie szybszy (>4 ml/h/kg) niż u osób dorosłych z hemofilią A (T $1 / 2$ około 10 h, klirens około $3 \mathrm{ml} / \mathrm{h} / \mathrm{kg}$ ) [85].

W odróżnieniu od czynnika VIII, między pdFIX i rFIX istnieją dość znaczne różnice farmakokinetyczne [98]. Wyrażają się one około 1,25-krotnie mniejszym IVR rFIX w porównaniu z pdFIX. Dożylne wstrzyknięcie 1 IU pdFIX na $1 \mathrm{~kg}$ mc. powoduje wzrost aktywności FIX w osoczu biorcy o około 1 IU/dl (IVR = 1), zaś wstrzyknięcie 1 IU rFIX na 1 kg mc. powoduje zwiększenie aktywności FIX w osoczu biorcy o około 0,8 IU/dl (IVR=0,8). Do obliczenia należnej dawki FIX stosuje się wzory [92-96]:

Dawka pdFIX (IU) = pożądane zwiększenie aktywności FIX w osoczu biorcy (\%) x masa ciała $(\mathrm{kg})$

Dawka rFIX (IU) = pożądane zwiększenie aktywności FIX w osoczu biorcy (\%) x masa ciała (kg) x 1,25

Częstotliwość dawek wynika z czasu biologicznego półtrwania FIX, który wynosi około 24 h (także w tym przypadku obserwuje się indywidualne wahania). Zależnie od sytuacji klinicznej wstrzyknięcia rFIX ( $\mathrm{T} 1 / 2$ 18-24 h, klirens 7,5$9,1 \mathrm{ml} / \mathrm{h} / \mathrm{kg}$ ) i pdFIX (T $1 / 2$ 29-43 h, klirens 3,8-5,4 ml/h/kg) powtarza się co 12, 18 lub $24 \mathrm{~h}$ [98]. Tak jak w przypadku 
Tabela III - Sugerowana docelowa aktywność FVIII i FIX w osoczu pacjentów z hemofilią A i B oraz czas stosowania

koncentratów FVIII i FIX w wybranych sytuacjach klinicznych

Table III - Suggested FVIII and FIX plasma levels and duration of administration of FVIII and FIX concentrates in patients with haemophilia $A$ and $B$ in various clinical settings

\begin{tabular}{|c|c|c|c|c|}
\hline \multirow[t]{2}{*}{ Wskazanie } & \multicolumn{2}{|c|}{ Hemofilia A } & \multicolumn{2}{|c|}{ Hemofilia B } \\
\hline & $\begin{array}{c}\text { Docelowa } \\
\text { aktywność w } \\
\text { osoczu (IU/dl) }\end{array}$ & Czas leczenia (dni) & $\begin{array}{c}\text { Docelowa } \\
\text { aktywność w } \\
\text { osoczu (IU/dl) }\end{array}$ & Czas leczenia (dni) \\
\hline $\begin{array}{l}\text { Wylewy krwi do stawów } \\
\text { i mięśni (z wyjątkiem } \\
\text { biodrowo-lędźwiowego), } \\
\text { krwawienia z nosa i dziąseł }\end{array}$ & $40-60$ & $\begin{array}{l}\text { 1-2, jeśli efekt zbyt } \\
\text { słaby rozważyć } \\
\text { zwiększenie dawki i } \\
\text { przedłużyć czas leczenia }\end{array}$ & $40-60$ & $\begin{array}{l}\text { 1-2, jeśli efekt zbyt słaby } \\
\text { rozważyć zwiększenie } \\
\text { dawki i przedłużyć czas } \\
\text { leczenia }\end{array}$ \\
\hline Mięsień biodrowo-lędźwiowy: & $\begin{array}{l}\text { - początkowo: } 80-100 \\
\text { - następnie: } 30-60\end{array}$ & $\begin{array}{l}1-2 \\
3-5, \text { niekiedy dłużej } \\
\text { + wtórna profilaktyka } \\
\text { w czasie rehabilitacji }\end{array}$ & $\begin{array}{l}\text { początkowo: } 60-80 \\
\text { - następnie: } 30-60\end{array}$ & $\begin{array}{l}1-2 \\
3-5, \text { niekiedy dłużej } \\
\text { + wtórna profilaktyka } \\
\text { w czasie rehabilitacji }\end{array}$ \\
\hline $\begin{array}{l}\text { Centralny układ } \\
\text { nerwowy/głowa: }\end{array}$ & $\begin{array}{l}\text { - początkowo: } 80-100 \\
\text { - następnie: } 50\end{array}$ & $\begin{array}{l}\text { 1-7 } \\
\text { 8-21, niekiedy dłużej } \\
\text { + wtórna profilaktyka }\end{array}$ & $\begin{array}{l}\text { - początkowo: } 60-80 \\
\text { - następnie: } 30\end{array}$ & $\begin{array}{l}\text { 1-7 } \\
\text { 8-21, niekiedy dłużej } \\
\text { + wtórna profilaktyka }\end{array}$ \\
\hline $\begin{array}{l}\text { Wylewy krwi do } \\
\text { dna jamy ustnej i szyi }\end{array}$ & $\begin{array}{l}\text { - początkowo: } 80-100 \\
\text { - następnie: } 50\end{array}$ & $\begin{array}{l}\text { 1-7 } \\
\text { 8-14, niekiedy dłużej } \\
\text { + wtórna profilaktyka }\end{array}$ & $\begin{array}{l}\text { - początkowo: } 60-80 \\
\text { - następnie: } 30\end{array}$ & $\begin{array}{l}\text { 1-7 } \\
\text { 8-14, niekiedy dłużej } \\
\text { + wtórna profilaktyka }\end{array}$ \\
\hline $\begin{array}{r}\text { Krwawienie z p. } \\
\text { pokarmowego }\end{array}$ & $\begin{array}{l}\text { - początkowo: 80-100 } \\
\text { - następnie: } 50\end{array}$ & $\begin{array}{l}1-7 \\
8-14\end{array}$ & $\begin{array}{l}\text { - początkowo: } 60-80 \\
\text { - następnie: } 30\end{array}$ & $\begin{array}{l}1-7 \\
8-14\end{array}$ \\
\hline $\begin{array}{l}\text { Istotny klinicznie } \\
\text { krwiomocz }\end{array}$ & 50 & $3-5$ & 40 & $3-5$ \\
\hline Głębokie zranienia & 50 & $5-7$ & 40 & $5-7$ \\
\hline $\begin{array}{r}\text { Duże operacje } \\
\text { chirurgiczne }\end{array}$ & $\begin{array}{l}\text { - przed operacją: } 80-100 \\
\text { - po operacji: } \\
\text { Dni 1-3: } 60-80 \\
\text { Dni 4-6: } 40-60 \\
\text { Dni 7-14: } 30-50\end{array}$ & & $\begin{array}{l}\text { - przed operacją: } 60-80 \\
\text { - po operacji: } \\
\text { Dni 1-3: } 40-60 \\
\text { Dni 4-6: } 30-50 \\
\text { Dni 7-14: } 20-40\end{array}$ & \\
\hline $\begin{array}{r}\text { Małe operacje } \\
\text { chirurgiczne }\end{array}$ & $\begin{array}{l}\text { - przed operacją: } 50-80 \\
\text { - po operacji: } 30-80 \text { przez } \\
\text { rodzaju zabiegu) }\end{array}$ & 1-5 dni (zależnie od & $\begin{array}{l}\text { - przed operacją: } 50-80 \\
\text { - po operacji: } 30-60 \text { przez } \\
\text { rodzaju zabiegu) }\end{array}$ & 1-5 dni (zależnie od \\
\hline Usuwanie zębów* & 50 & $\begin{array}{l}\text { Jednorazowo przed } \\
\text { zabiegiem. W przypadku } \\
\text { złożonych zabiegów } \\
\text { ekstrakcji czas leczenia } \\
\text { wydłuża się. }\end{array}$ & 40 & $\begin{array}{l}\text { Jednorazowo przed } \\
\text { zabiegiem. W przypadku } \\
\text { złożonych zabiegów } \\
\text { ekstrakcji czas leczenia } \\
\text { wydłuża się. }\end{array}$ \\
\hline $\begin{array}{l}\text { Od dnia ekstrakcji przez kol } \\
\text { Uwaga: lekiem z wyboru w łą } \\
60 \text { min.) dożylnej infuzji. Lek t } \\
\text { nosa). } \\
\text { Uwaga: zabiegi chirurgiczne } \\
\text { monitorowania leczenia (m.in } \\
\text { Nijmegen) przez co najmniej }\end{array}$ & $\begin{array}{l}\text { 7-10 dni lek antyfibryno } \\
\text { j hemofilii A z aktywno } \\
\text { ożna również stosować } \\
\text { zenie krwawień zagraż } \\
\text { naczanie aktywności cz } \\
\text { w tygodniu. }\end{array}$ & $\begin{array}{l}\text { zny, np. kwas traneksar } \\
\text { FVIII }>10 \text { IU/dl jest desr } \\
\text { osowo w dawce } 300 \mu g \\
\text { ych życiu wyłącznie w } \\
\text { ików krzepnięcia, ozna }\end{array}$ & $\begin{array}{l}\text { w dawce około } 10-15 \mathrm{~m} \\
\text { syna, podawana w daw } \\
\text { słych i } 150 \mu \mathrm{g} \text { u dzieci ( } \\
\text { dkach dysponujących } \\
\text { miana inhibitora met }\end{array}$ & $\begin{array}{l}\mathrm{kg} \mathrm{mc} \text {. co } 8 \mathrm{~h} \text {. } \\
0,3 \mu \mathrm{g} / \mathrm{kg} \text { w powolnej (30- } \\
\text { mopresyna w aerozolu do } \\
\text { żliwością laboratoryjnego } \\
\text { ą Bethesda w modyfikacji }\end{array}$ \\
\hline
\end{tabular}

FVIII $w$ hemofilii A, T $1 / 2$ FIX $u$ dzieci $z$ hemofilią $B$ jest krótszy (a klirens szybszy) niż u osób dorosłych chorych na hemofilię B.

W przypadku konieczności stosowania intensywnego leczenia substytucyjnego przez co najmniej kilka dni, jak to ma miejsce w przypadku zabiegów operacyjnych i krwawień zagrażających życiu, obowiązuje zasada laboratoryjnego monitorowania aktywności niedoborowego czynnika krzepnięcia co najmniej raz na dobę, w próbce krwi pobranej przed kolejną dawką leku (oznacza się nadir aktywności). Dobór dawek odpowiedniego czynnika krzepnięcia powinien $\mathrm{w}$ takich sytuacjach następować na podstawie uzyskanych wyników oznaczeń w kolejnych dniach terapii.
Zasady monitorowania leczenia substytucyjnego w ramach długoterminowej profilaktyki przedstawiono $\mathrm{w}$ dalszej części niniejszych wytycznych.

\section{Koncentraty rFVIII i rFIX o przedłużonym okresie półtrwania (extended half-life; EHLrFVIII i EHLrFIX)}

W 2014 roku w USA, Kanadzie, Australii i Japonii zarejestrowano dwa koncentraty o przedłużonym czasie działania: 1) rFVIII połączony $z$ fragmentem Fc immunoglobuliny G (recombinant factor VIII fusion to FcIG; rFVIII-Fc, efmoroctocogum alfa) oraz 2) rekombinowany czynnik IX połączony $\mathrm{z}$ fragmentem Fc immunoglobuliny G (recombinant factor IX fusion to FCIG; rFIX-Fc, eftrenonacog alfa) [99]. Zarejestrowanie 
obu leków było poprzedzone intensywnymi badaniami klinicznymi, w których udowodniono skuteczność i bezpieczeństwo obydwu koncentratów w profilaktyce i leczeniu krwawień u młodocianych i dorosłych chorych na hemofilię A i B, uprzednio leczonych koncentratami czynników krzepnięcia (previously treated patients; PTP) [100, 101].

Szczególnie obiecujące są wyniki uzyskane u pacjentów z hemofilią B [100]. Czas biologicznego półtrwania rFIX-Fc wynosi 82,1 h. Przy podawaniu rFIX-Fc w dawce $20 \mathrm{IU} / \mathrm{kg}$ co 7 dni lub $40 \mathrm{IU} / \mathrm{kg}$ co $10 \mathrm{dni}$ albo $100 \mathrm{IU} / \mathrm{kg}$ co $14 \mathrm{dni}$ u wielu pacjentów z ciężką hemofilią B udaje się stale utrzymywać aktywność FIX w osoczu >1-3 IU/dl. Innymi słowy, u tych pacjentów jest szansa zmniejszenia liczby dożylnych wstrzyknięć FIX w długoterminowej profilaktyce krwawień o 50-80\% przy zachowaniu co najmniej tej samej skuteczności co obecnie stosowane rekombinowane koncentraty FIX wstrzykiwane 2 razy $\mathrm{w}$ tygodniu. Żaden $\mathrm{z}$ pacjentów otrzymujących rFIX-Fc w ramach prób klinicznych nie wytworzył inhibitora wobec czynnika IX.

Mniej spektakularne wyniki dla rFVIII-Fc tłumaczy się wiązaniem wstrzykniętego FVIII z czynnikiem von Willebranda, który determinuje tempo klirensu FVIII (zarówno endogennego jak i egzogennego) [102, 103]. Czas biologicznego półtrwania rFVIII-Fc wynosi 19,0 h, co oznacza, że jest około 1,5-krotnie dłuższy w porównaniu ze standardowymi rFVIII. Czyli w praktyce odstępy między wstrzyknięciami u pacjenta z ciężką hemofilią A otrzymującego długoterminową profilaktykę krwawień można wydłużyć ok. 3-5 dni, a u wybranych chorych $\mathrm{z}$ bardzo korzystnymi parametrami farmakokinetycznymi, nawet do 7 dni. W badaniu klinicznym 3. fazy „roczna częstość krwawień” (annualized bleeding rate; $\mathrm{ABR}$ ) u pacjentów otrzymujących regularne wstrzyknięcia rFVIII-Fc co 3 dni, 2 razy w tygodniu, co 4 dni i co 5 dni wyniosła odpowiednio 0,0; 0,0; 2,0 i 2,0 [101].

Badania kliniczne wykazały także, że nowo zarejestrowane koncentraty są skuteczne i bezpieczne w osłonie hemostatycznej zabiegów chirurgicznych, a docelowa aktywność niedoborowego czynnika krzepnięcia w okresie okołooperacyjnym powinna być taka sama jak przy stosowaniu standardowych koncentratów FVIII i FIX. Amerykańska Agencja do spraw Żywności i Leków (Food and Drug Administration; FDA) zaleca do monitorowania aktywności rFIX-Fc stosowanie testów koagulacyjnych z użyciem kwasu elagowego, zaś do monitorowania rFVIII-Fc - odpowiednich testów chromogennych i koagulacyjnych [99].

Koncentrat rekombinowanego czynnika VIII o przedłużonym działaniu (rFVIII-Fc) został zarejestrowany w UE w listopadzie 2015 r. (p. niżej).

\section{Desmopresyna}

Desmopresyna jest pochodną hormonu antydiuretycznego [104]. U osób zdrowych, a także u osób chorych na łagodną hemofilię A i u pacjentów z wybranymi (łagodnymi) postaciami VWD, DDAVP powoduje przejściowe zwiększenie zawartości VWF i FVIII w krwiobiegu. Mechanizm działania DDAVP polega na stymulacji uwalniania FVIII i czynnika von Willebranda, magazynowanych w śródbłonku naczyniowym do osocza, prawdopodobnie poprzez pobudzenie receptorów wazopresynowych typu 2 (V2) w szlaku zależnym od cyklicznego adenozynomonofosforanu (cAMP) [105]. W ciągu 3-5 dni od rozpoczęcia podawania DDAVP dochodzi do wyczerpania śródbłonkowych magazynów FVIII i VWF i dlatego dalsze stosowanie leku nie ma uzasadnienia.

Ponieważ niektórzy pacjenci mogą być oporni na działanie DDVP, przed leczniczym zastosowaniem tego leku należy przeprowadzić test potwierdzający wpływ DDAVP na zwiększenie zawartości czynnika VIII w osoczu chorego (60 min. po podaniu DDAVP w dawce $0,3 \mu \mathrm{g} / \mathrm{kg}$ w dożylnym wlewie należy pobrać krew na oznaczenie aktywności FVIII; jeśli aktywność FVIII zwiększy się powyżej $50 \mathrm{IU} / \mathrm{dl}$, test z DDAVP uznaje się za pozytywny). Ze względu na antydiuretyczne działanie DDAVP, u chorych leczonych tym lekiem należy ograniczyć podaż płynów (nawet o 50\%). Nie powinno się stosować DDAVP u dzieci poniżej 2. r.ż, ponieważ skłonność do hiponatremii występuje u nich częściej niż w starszym wieku [106]. Opisywano przypadki powikłań zakrzepowych i zaostrzeń choroby niedokrwiennej serca podczas leczenia DDAVP u osób powyżej 60. r.ż. Desmopresynę podaje się w dawce $0,3 \mu \mathrm{g} / \mathrm{kg}$ mc., rozcieńczoną w 30$100 \mathrm{ml} 0,9 \% \mathrm{NaCl}$, we wlewie dożylnym trwającym co najmniej $30 \mathrm{~min}$. Od $2014 \mathrm{r}$. w Polsce jest dostępny preparat DDAVP w postaci inhalacji donosowych, który podaje się dorosłym w dawce $300 \mu \mathrm{g}$, a dzieciom o masie ciała poniżej $40 \mathrm{~kg}-150 \mu \mathrm{g}$.

\section{Leki wspomagające}

Bardzo pożyteczne w hamowaniu krwawień śluzówkowych w obrębie jamy ustnej, nosa, przewodu pokarmowego, a u objawowych nosicielek hemofilii także z dróg rodnych są leki antyfibrynolityczne. W lecznictwie dostępny jest syntetyczny analog lizyny o właściwościach hamujących fibrynolizę i stabilizujących skrzep - kwas traneksamowy (TXA) [107]. Wykazujący podobne działanie, ale działający słabiej i prowokujący dość często działania niepożądane kwas epsilonaminokapronowy (EACA) został wycofany z użycia kilka lat temu. Dorosłym TXA podaje się dożylnie lub doustnie w dawce $1,0 \mathrm{~g}$ co $6-8 \mathrm{~h}$, zaś dzieciom - $20 \mathrm{mg} / \mathrm{kg}$ mc./dobę, także w 3-4 dawek. Wstrzyknięcia dożylne TXA należy wykonywać powoli z szybkością $100 \mathrm{mg} / \mathrm{min}$. U pacjentów z krwawieniami ze śluzówek jamy ustnej TXA można stosować miejscowo w postaci 5\% wodnego roztworu. Zazwyczaj zaleca się w takiej sytuacji płukanie jamy ustnej $10 \mathrm{ml}$ roztworu w odstępach 4-6h. Wodny roztwór TXA można połykać (odpowiada to przyjęciu $500 \mathrm{mg}$ tabletki TXA). Kwas traneksamowy dostępny jest również w postaci ampułek do picia $(1 \mathrm{~g} / 10 \mathrm{ml})$, szczególnie wygodnej dla małych dzieci. Przeciwwskazaniem do stosowania TXA jest krwawienie z dróg moczowych, niewydolność nerek, ostry proces zakrzepowo-zatorowy, a także wystąpienie zaburzenia widzenia kolorów w trakcie przyjmowania TXA. Inne leki wspomagające to środki hemostatyczne przeznaczone do stosowania miejscowego, do których należą: gąbka żelatynowa, odwodniona celuloza, regenerowana utleniona celuloza, drobnowłóknikowy kolagen, klej fibrynowy, trombina oraz żele płytkowe. Środki te wspomagają proces krzepnięcie krwi, a ich działanie polega na wytworzeniu rusztowania, na którym powstaje skrzep, oraz niewielkim ucisku mechanicznym 
powierzchni rany [108-110]. Środki te wykorzystuje się przede wszystkim w chirurgii ogólnej, ortopedycznej i stomatologicznej.

Wytyczne odnośnie do wyboru koncentratów czynników krzepnięcia i innych leków hemostatycznych stosowanych w leczeniu chorych na hemofilię A i B

1. W profilaktyce i leczeniu krwawień w umiarkowanej i ciężkiej hemofilii zaleca się uzupełnianie niedoborowego czynnika krzepnięcia (tzw. leczenie substytucyjne) dożylnymi wstrzyknięciami liofilizowanych koncentratów czynników krzepnięcia poddawanych skutecznym procedurom inaktywacji wirusów.

2. Ze względu na mniejsze ryzyko przeniesienia czynników zakaźnych (także dotąd nie opisanych) przez koncentraty rekombinowanych czynników krzepnięcia $\mathrm{w}$ porównaniu $\mathrm{z}$ koncentratami osoczopochodnymi, sugeruje się stosowanie koncentratów rekombinowanych. Zalecenie to dotyczy wszystkich pacjentów niezależnie od wieku, a zwłaszcza tych, którzy nie są zakażeni wirusami HCV, HBV i HIV.

3. W wybranych przypadkach hemofilii A bardziej korzystne może być stosowanie koncentratów FVIII zawierających czynnik von Willebranda.

4. Lekiem hemostatycznym $\mathrm{z}$ wyboru $\mathrm{w}$ leczeniu krwawień u chorych na łagodną hemofilię A jest desmopresyna. Jeśli odpowiedź na to leczenie jest niewystarczające lub występują przeciwwskazania do stosowania desmopresyny, lub pojawiają się działania niepożądane po jej zastosowaniu, włącza się leczenie substytucyjne.

5. Niepoddane procedurom inaktywacji wirusów osocze świeżo mrożone (zawiera FVIII i FIX) i krioprecypitat (zawiera FVIII, ale nie zawiera FIX) nie powinny być stosowane $\mathrm{w}$ leczeniu substytucyjnym hemofilii, chyba że krwawienie wymaga natychmiastowego leczenia, a liofilizowane koncentraty nie są dostępne.

6. Nie zaleca się stosowania koncentratów zespołu protrombiny w leczeniu krwawień w hemofilii $\mathrm{B}$, ze względu na ryzyko wystąpienia powikłań zakrzepowo-zatorowych.

7. W wybranych sytuacjach klinicznych zasadne jest stosowanie leków wspomagających, takich jak kwas traneksamowy i hemostatyczne środki działające miejscowo.

8. W chwili, kiedy ukończono formułowanie niniejszych wytycznych, koncentraty czynników krzepnięcia o przedłużonym czasie działania nie były stosowane w Polsce. Koncentrat rekombinowanego czynnika VIII o przedłużonym działaniu (rFVIII-Fc, efmoroctocogum alfa)* został zarejestrowany w UE w listopadzie 2015 r.

*) Stosowanie koncentratu rFVIII-FC:

Leczenie na żadanie

Przeliczenie wymaganej dawki rFVIII-Fc opiera się na założeniu, że 1 IU czynnika VIII na $1 \mathrm{~kg}$ masy ciała zwiększa aktywność czynnika VIII w osoczu o 2 j.m./dl. Wymagane dawkowanie przeliczane jest wg wzoru: Wymagane jednostki = masa ciała $(\mathrm{kg})$ x pożądany wzrost aktywności czynnika VIII (\%) (IU/dl) x 0,5 (IU/kg na IU/dl)

Profilaktyka

W celach profilaktyki długoterminowej zalecana dawka to $50 \mathrm{IU} / \mathrm{kg}$ co 3-5 dni. Dawkę można dostosowywać na podstawie oceny skuteczności u danego pacjenta, w zakresie 25-65 IU/kg. W niektórych przypadkach, szczególnie u pacjentów w młodszym wieku, konieczne jest podawanie tego czynnika częściej lub w większych dawkach. W przypadku pacjentów, u których lekarz uznał cotygodniową profilaktykę za właściwe postępowanie, zalecana dawka to $65 \mathrm{IU} / \mathrm{kg}$.

\section{Strategia postępowania}

Nadrzędnym celem w postępowaniu z chorym na ciężką hemofilię powinno być efektywne zapobieganie samoistnym krwawieniom do stawów i mięśni, wylewom krwi zagrażającym życiu, w tym - śródczaszkowym, prewencja krwawień w okresie okołooperacyjnym oraz skuteczne zwalczanie wszystkich ostrych epizodów krwotocznych [111]. Podawanie leków hemostatycznych w celu zapobiegania krwawieniom określa się mianem profilaktyki, zaś stosowanie ich w momencie aktywnego krwawienia - leczeniem na żądanie (on-demand) [18, 21]. W tabeli IV przedstawiono definicje różnych form leczenia substytucyjnego w hemofilii.

\section{Długoterminowa pierwotna i wtórna profilaktyka}

Podstawą nowoczesnego leczenia hemofilii jest długoterminowa profilaktyka krwawień, rozpoczęta w pierwszych latach życia [112]. W dwóch randomizowanych badaniach klinicznych wykazano, że w porównaniu z leczeniem według zasady „na żądanie”, długoterminowa profilaktyka krwawień u dzieci z ciężką hemofilią A z zastosowaniem rFVIII prowadzi do zmniejszenia częstości krwawień, ograniczenia rozwoju artropatii oraz podniesienia jakości życia zależnej od zdrowia [113, 114].

Wyróżnia się cztery podstawowe modele długoterminowej profilaktyki w hemofilii A: model szwedzki, model holenderski, model kanadyjski i amerykański [113, 115-121].

1) $W$ modelu szwedzkim profilaktykę rozpoczyna się na przełomie 1. i 2. roku życia przed wystąpieniem pierwszego istotnego klinicznie krwawienia. Koncentrat FVIII wstrzykuje się co drugi dzień lub 3 razy w tygodniu. Zazwyczaj dawki FVIII mieszczą się w przedziale 25-40 IU/kg. Dawkowanie dostosowuje się tak, aby aktywność niedoborowego czynnika krzepnięcia w osoczu nie była nigdy mniejsza niż $1 \mathrm{IU} / \mathrm{dl}$ oraz aby w ogóle nie występowały samoistne krwawienia. Zużycie koncentratu FVIII (i FIX) w ramach "szwedzkiej” profilaktyki oszacowano w badaniu obserwacyjnym na 4730-7818 IU/kg/rok w grupie starszych pacjentów i 5305-8915 IU/kg/rok w grupie młodszych pacjentów [122]. Jak wykazały badania kliniczne, tak leczeni pacjenci nie mają żadnych oznak artropatii 
Tabela IV - Definicje leczenia substytucyjnego w hemofilii Table IV - Definitions of replacement therapy in haemophilia

\author{
Leczenie epizodyczne \\ („na żądanie”) \\ Długoterminowa profilaktyka \\ Pierwotna profilaktyka
}

Wtórna profilaktyka

Trzeciorzędowa profilaktyka

Inne formy profilaktyki

Okresowa profilaktyka
Wstrzyknięcie koncentratu niedoborowego czynnika krzepnięcia w celu zatrzymania krwawienia.

Regularne, długoterminowe wstrzykiwanie koncentratu niedoborowego czynnika krzepnięcia, rozpoczęte przed wystąpieniem udokumentowanych zmian zwyrodnieniowych w stawach, wykazanych za pomocą badania przedmiotowego i/lub badań obrazowych oraz przed wystąpieniem drugiego, jawnego klinicznie krwawienia do dużego stawu u pacjenta przed ukończeniem 3. roku życia Regularne, długoterminowe wstrzykiwanie koncentratu niedoborowego czynnika krzepnięcia, rozpoczęte po wystąpieniu 2 lub więcej wylewów krwi do dużych stawów" i przed wystąpieniem udokumentowanych zmian zwyrodnieniowych w stawach, wykazanych za pomocą badania przedmiotowego i badań obrazowych

Regularne, długoterminowe wstrzykiwanie koncentratu niedoborowego czynnika krzepnięcia rozpoczęte po wystąpieniu udokumentowanych zmian zwyrodnieniowych w stawach, wykazanych za pomocą badania przedmiotowego i zwykłych badań rentgenowskich zajętych stawów

Wstrzykiwanie koncentratu niedoborowego czynnika krzepnięcia w celach profilaktycznych przez czas krótszy niż 45 tygodni w roku

długoterminowe - oznacza zamiar stosowania koncentratu przez 52 tygodnie w roku i realizowane przez co najmniej 45 tygodni (85\%) w roku

duże stawy - skokowo-goleniowe, kolanowe, biodrowe, łokciowe i barkowe

w badaniach fizykalnym i radiologicznym, wykonanych w 7.-10. r.ż. Model szwedzki określa się mianem profilaktyki wysokodawkowanej. Przeciętny dorosły chory na hemofilię A w Szwecji, w ramach długoterminowej profilaktyki, otrzymuje obecnie FVIII 3 razy w tygodniu w dawce 2000 IU lub co drugi dzień 1500 IU [121].

2) W modelu holenderskim (określanym jako model pośrednich dawek) profilaktykę inicjuje się po wystąpieniu 1-2 krwawień do stawów lub po wystąpieniu w ciągu jednego miesiąca 2 krwawień pozastawowych, wymagających leczenia substytucyjnego. Średni wiek rozpoczynania profilaktyki w modelu holenderskim wyniósł 3,9 roku [123]. Dawki są mniejsze (zwykle około 15 IU FVIII/kg 3 razy w tygodniu) niż w modelu szwedzkim, a w ocenie skuteczności profilaktyki najważniejszą role odgrywa ocena kliniczna (minimalna liczba krwawień), a nie laboratoryjne monitorowanie i dążenie do utrzymania aktywności niedoborowego czynnika krzepnięcia $>1$ IU/dl. Zużycie koncentratu FVIII w grupie holonderskiej wyniosło $2900 \mathrm{IU} / \mathrm{kg} / \mathrm{rok}$, a więc znacznie mniej niż $w$ grupie szwedzkiej, ale w badaniach fizykalnym i radiologicznym wykonanych około 8. r.ż. zaobserwowano cechy (minimalnej) artropatii. Przeciętny dorosły chory na hemofilię A w Holandii, w ramach długoterminowej profilaktyki otrzymuje obecnie FVIII 3 razy w tygodniu w dawce 1000 IU [121].

3) W modelu kanadyjskim, określanym mianem „modelem wzrastających dawek" (dose-escalation regimen) profilaktykę rozpoczyna się od podawania FVIII w dawce $50 \mathrm{IU} / \mathrm{kg}$ jeden raz w tygodniu. Jeśli w trakcie leczenia pojawiają się krwawienia, zmienia się sposób dawkowania FVIII na 30 IU/kg 2 razy w tygodniu. Jeśli w dalszym ciągu występują krwawienia, FVIII zaczyna się podawać w dawce $25 \mathrm{IU} / \mathrm{kg}$ co drugi dzień. Jak wykazano w badaniu klinicznym, po 5 latach leczenia 40\% chłopców z ciężką hemofilią A pozostało przy dawkowaniu jeden raz w tygodniu [124]. Zużycie koncentratu FVIII w modelu kanadyjskim wyniosło 3656 IU/kg/rok. Najbardziej rozczarowująca była obserwacja, że w ciągu kilku lat leczenia aż u 30\% chłopców występowały regularne krwawienia do wybranych stawów (tzw. target joints), a w badaniu MRI 50\% pacjentów wykazywało zmiany chrzęstno-kostne w stawach [125].

4) W modelu amerykańskim stosuje się FVIII w dawce 25 IU/kg co drugi dzień. W badaniu Joint Outcome Study wykazano, że 93\% dzieci z ciężką hemofilią A leczonych według tego schematu przez około 4 lata miało całkowicie zdrowe stawy w MRI [113]. Grupę kontrolną w tym badaniu stanowili chłopcy z ciężką hemofilią A leczeni według zasady „na żądanie”, tj. FVIIII w dawce $40 \mathrm{IU} / \mathrm{kg}$ $\mathrm{w}$ chwili wystąpienia krwawienia oraz dwie dodatkowe iniekcje FVIII w dawce $20 \mathrm{IU} / \mathrm{kg} 24 \mathrm{~h} \mathrm{i} 72 \mathrm{~h}$ od chwili wystąpienia krwawienia (dopuszczalne było także stosowanie w grupie kontrolnej FVIII w dawce $20 \mathrm{IU} / \mathrm{kg}$ co drugi dzień maksymalnie przez 4 tygodnie od wystąpienia krwawienia). Tyko 55\% chłopców leczonych według modelu „na żądanie” nie miało cech artropatii w badaniu MRI wykonanym po około 4 latach obserwacji. Zużycie koncentratu FVIII w grupie leczonej profilaktycznie wyniosło $6000 \mathrm{IU} / \mathrm{kg} / \mathrm{rok}$, a w grupie leczonej „na żądanie” - $2500 \mathrm{IU} / \mathrm{kg} / \mathrm{rok}$. Warto podkreślić, że u kilku chłopców wykryto badaniem MRI zmiany zwyrodnieniowe w stawach pomimo braku jawnych klinicznie cech krwawienia dostawowego. Uważa się, że u części pacjentów mogą występować tzw. subkliniczne (bezobjawowe) krwawienia do stawów; mechanizm tego zjawiska nie jest znany.

Dane piśmiennictwa na temat długoterminowej profilaktyki krwawień u pacjentów z hemofilią $B$ nie są tak liczne jak w przypadku hemofilii A. Wyniki uzyskane w kilku próbach klinicznych wskazują, że dawkowanie koncentratu rFIX powinno oscylować między 40 a 100 IU/ $\mathrm{kg}$, a częstość wstrzyknięć - między 1 a 3 razy w tygodniu [126]. Biorąc pod uwagę różnice właściwości farmakokinetycznych rekombinowanego i osoczopochodnego FIX, dawki rFIX mogą być większe niż pdFIX, choć ostatnio opublikowana analiza sposobu dawkowania koncentratów FIX we Włoszech wskazała, że de facto różnice te są bardzo małe [127]. 


\section{Trzeciorzędowa profilaktyka u dzieci i dorosłych z rozwiniętą artropatia}

Choć jak dotąd nie ustalono, czy lepiej zacząć profilaktykę przed wystąpieniem pierwszego krwawienia do stawu, czy też lepiej poczekać z inicjacją regularnych wstrzyknięć niedoborowego czynnika krzepnięcia do pierwszego, istotnego klinicznie krwawienia (niekiedy ma ono miejsce nie $\mathrm{w}$ 1.-2. r.ż., lecz $\mathrm{w} \mathrm{np} . \mathrm{w}$ 3.-4. r.z..), to nie ulega żadnej wątpliwości, że profilaktyka powinna być rozpoczęta we wczesnym dzieciństwie i nie później niż po pierwszych kilku krwawieniach [90]. Jak wykazali badacze holenderscy, każdy rok opóźnienia profilaktyki krwawień u pacjenta z ciężką hemofilią po wystąpieniu pierwszego krwawienia do stawu przyczynia się do pogorszenia stanu narządu ruchu o $8 \%$, ocenionego około 20. r.ż. w radiologicznej skali Petterssona [128].

Znacznie mniej danych klinicznych zgromadzono odnośnie do stosowania trzeciorzędowej profilaktyki krwawień [129]. Niemniej, w 2013 roku Manco-Johnson i wsp. [130] opublikowali wyniki randomizowanej próby klinicznej z grupą kontrolną, której celem było porównanie skuteczności trzeciorzędowej profilaktyki (FVIII w dawce $25 \mathrm{IU} / \mathrm{kg}$ 3 razy w tygodniu) krwawień z leczeniem „na żądanie” $\mathrm{w}$ grupie 84 dorosłych pacjentów $\mathrm{z}$ ciężką hemofilią A (SPINNART). Profilaktyka przyczyniła się do istotnego zmniejszenia częstości występowania krwawień (mediana 0 krwawień/rok w grupie profilaktyki us 27,9 krwawieńrok w grupie „na żądanie”). Podobne wyniki uzyskał Valentino i wsp. [131], którzy w grupie 66 pacjentów w wieku 7-59 lat zanotowali przeciętnie blisko 44 krwawienia/rok przy leczeniu według zasady „na żądanie” w porównaniu z 1 krwawieniem/rok w grupie leczonej profilaktycznie $(20-40 \mathrm{IU} / \mathrm{kg}$ co drugi dzień z utrzymywaniem aktywności FVIII w osoczu stale $>1 \mathrm{IU} / \mathrm{dl}$ ) i 2 krwawieniami/rok w grupie otrzymującej profilaktykę dostosowaną do parametrów PK (20-80 IU/kg co trzeci dzień z utrzymywaniem aktywności FVIII w osoczu stale $>1 \mathrm{IU} / \mathrm{dl})$.

Windyga i wsp. [132] oraz Valentino i wsp. [133] dostarczyli dowodów na większą skuteczność trzeciorzędowej profilaktyki krwawień w porównaniu z leczeniem „na żądanie” u pacjentów z ciężką hemofilią B. W badaniu Windygi i wsp. [132] rFIX stosowano w profilaktyce w średniej dawce $50 \mathrm{IU} / \mathrm{kg}$ wstrzykiwanej 2 razy w tygodniu, zaś w badaniu Valentino i wsp. [133] - rFIX podawano w profilaktyce w średniej dawce $50 \mathrm{IU} / \mathrm{kg} 2$ razy w tygodniu albo w dawce około $100 \mathrm{IU} / \mathrm{kg}$ jeden raz w tygodniu. Wyniki ww. badań wskazują, że u pacjentów zarówno z hemofilią A, jak i B, z rozwiniętą artropatią, doznających licznych krwawien dostawowych, warto rozważyć zmianę sposobu leczenia $\mathrm{z}$ modelu "na żądanie” na długoterminową profilaktykę [129, 134].

\section{Indywidualizacja leczenia substytucyjnego hemofilii}

W ostatnich kilku latach zwrócono baczną uwagę na potrzebę indywidualizacji (personalizacji) leczenia hemofilii, podkreślając, że nie ma jednego, uniwersalnego schematu dawkowania niedoborowego czynnika krzepnięcia w długoterminowej profilaktyce, który zabezpieczyłby optymalnie potrzeby wszystkich pacjentów [135].
Valentino [90] podkreślił, że przygotowując plan długoterminowej profilaktyki dla określonego pacjenta, należy wziąć pod uwagę takie czynniki, jak: 1) indywidualne parametry farmakokinetyczne (PK), z których najważniejszy w przypadku długoterminowej profilaktyki, to $\mathrm{T} 1 / 2$ niedoborowego czynnika krzepnięcia; 2) fenotyp krwotoczny (ciężki us łagodny); 3) wiek rozpoczęcia profilaktyki (należy unikać opóźnień w jej inicjowaniu); 4) aktywność fizyczną pacjenta (duża aktywność młodych pacjentów us zazwyczaj mniejsza aktywność osób starszych); 5) stosowanie się (adherence) do wymogów reżimu długoterminowej profilaktyki, przede wszystkim wyrażające się systematycznością w stosowaniu wstrzyknięć niedoborowego czynnika krzepnięcia (bez omijania zaplanowanych wstrzyknięć).

Znajomość indywidualnego profilu PK odgrywa ważną rolę w wyborze optymalnego modelu profilaktycznego, co podkreśla przykład podany przez Collinsa i wsp. [88], którzy zwrócili uwagę, że w badaniach populacyjnych przeprowadzonych $\mathrm{w}$ grupie pacjentów $\mathrm{z}$ ciężką hemofilią $\mathrm{A}$, okres półtrwania FVIII wahał się od 6 do 25 h (sic!) [88]. Zastosowanie takiego samego schematu dawkowania FVIII (w przeliczeniu na kg mc.) u pacjenta $z$ bardzo krótkim i bardzo długim okresem półtrwania będzie prowadziło albo do niepotrzebnego przedawkowania koncentratu (i zwiększenia kosztów terapii) albo do niedostatecznego zabezpieczenia chorego przed występowaniem krwawien. Warto także nadmienić, że o ile IVR (odzysk in vivo) jest ważnym parametrem PK przy wyborze dawki w leczeniu aktywnego krwawienia (kiedy najważniejszy jest $C_{\max }$ ), o tyle IVR nie odgrywa większej roli przy planowaniu długoterminowej profilaktyki, w której najważniejszym parametrem jest utrzymywanie najniższej aktywności (trough level) niedoborowego czynnika krzepnięcia w osoczu powyżej pewnej wartości.

Określenie indywidualnego profilu PK nie jest łatwe, albowiem wiąże się $z$ wielokrotnym pobieraniem próbek krwi po wstrzyknięciu określonej dawki niedoborowego czynnika krzepnięcia. Co więcej, obliczenie poszczególnych parametrów PK także nie jest zadaniem prostym. Ostatnio jednak opublikowano wyniki badań, które wskazują, że do określenia indywidualnego profilu PK u chorych na hemofilię A i B wystarczą wyniki oznaczeń aktywności niedoborowego czynnika krzepnięcia wykonane w trzech próbkach krwi pobranych około 4,24 i $48 \mathrm{~h}$ po podaniu koncentratu [136, 137]. Uproszczenie badań farmakokinetycznych stało się możliwe dzięki wykorzystaniu statystycznego modelu Bayesa, którego istotą jest znajomość parametrów PK w większych populacjach chorych i odnoszenie wyników uzyskanych w pojedynczym przypadku do wyników populacyjnych [138]. Nadto $\mathrm{z}$ danych piśmiennictwa wynika, że producenci koncentratów czynników krzepnięcia są bliscy sfinalizowania prac nad kalkulatorem przeznaczonym do obliczania parametrów PK [91].

Koncepcja długoterminowej profilaktyki dostosowanej do indywidualnych parametrów PK i indywidualnych potrzeb pacjenta służy realizacji najbardziej ambitnego celu w terapii substytucyjnej hemofilii, czyli całkowitego wyeliminowania samoistnych krwawień przy równoczesnej optymalizacji zużycia koncentratów (minimalizowanie kosztów leczenia) i minimalizowaniu częstości dożylnych wstrzyknięć [131, 133, 
139]. Wypadkową tych działań jest zwiększona jakość życia zależna od zdrowia [140].

\section{Monitorowanie efektów profilaktyki}

Miernikiem skuteczności długoterminowej profilaktyki jest brak krwawień oraz brak zmian zwyrodnieniowych w stawach ocenianych badaniem fizykalnym i za pomocą odpowiednich technik obrazowych. Nadto, jak już wcześniej wspomniano, okresowo sprawdza się nadir aktywności niedoborowego czynnika krzepnięcia w osoczu pacjenta otrzymującego długoterminową profilaktykę.

Powodem do przeprowadzenia modyfikacji schematu profilaktyki może być zarówno brak jej skuteczności, np. wyrażający się występowaniem wylewów krwi lub - co zdarza się rzadziej - odchyleniami od normy w badaniach obrazowych stawów pomimo braku objawów krwawień do stawów, ale także poszukiwanie optymalnego (najniższego skutecznego) dawkowania koncentratu czynnika krzepnięcia u pacjentów, u których nie występują krwawienia, a nadir osoczowej aktywności niedoborowego czynnika krzepnięcia jest zbyt duży w stosunku do wartości ustalonej przy planowaniu indywidualnego schematu profilaktyki [90].

Do fizykalnej oceny stanu narządu ruchu wykorzystuje się obecnie najczęściej punktową skalę HJHS (Haemophilia Joint Health Score) [141, 142]. Oczywiście, badaniem fizykalnym nie można wykryć dyskretnych zmian zwyrodnieniowych w stawach, dlatego u dzieci otrzymujących koncentraty w ramach pierwotnej i wtórnej profilaktyki krwawień zaleca się dodatkowo okresowe badanie stawów za pomocą MRI [143]. Radiogramy (RTG), często wystarczające do oceny stawów u dorosłych pacjentów z rozwiniętą artropatią, nie są odpowiednio czułą metodą do wykrywania początkowych zmian zwyrodnieniowych w stawach $\mathrm{u}$ dzieci. Natomiast obrazy uzyskane w MRI pozwalają wykryć tak subtelne zmiany, jak przerost błony maziowej, złogi hemosyderyny czy zaczynające się zmiany chrzęstno-kostne. Wadą MRI są wysokie koszty badania oraz konieczność zastosowania sedacji u najmniejszych dzieci poddawanych badaniu. W celu ujednolicenia interpretacji wyników badania MRI opracowano kilka punktowych skal, z których najbardziej rekomendowaną jest skala IPSG (International Prophylaxis Study Group) [144].

Coraz częściej do oceny stawów u chorych na hemofilię wykorzystuje się badanie ultrasonograficzne (USG). Zalety USG, to małe koszty związane $\mathrm{z}$ badaniem, powszechna dostępność, możliwość wykrycia wczesnych zmian w stawach, takich jak obecność krwi, przerost błony maziowej i nadżerki niektórych struktur stawowych. Wadą USG jest dość słaba czułość w wykrywaniu ubytków chrzęstnych i torbieli kostnych oraz niemała rozbieżność wyników wynikająca z różnej interpretacji obrazów przez osoby wykonujące badanie. Tej ostatniej wadzie próbuje się zaradzić, tworząc punktowe skale ujednolicające interpretację obrazów uzyskanych w USG, np. skalę HEAD-US [145].

Do oceny aktywności fizycznej oraz jakości życia zależnej od zdrowia (health related quality of life; HRQoL) u chorych na hemofilię można wykorzystać wiele różnych skal, w tym m.in.: HAL (haemophilia activity list), FISH (functional independence score in haemophilia), Haem-A-QoL czy przeznaczoną do oceny HRQoL wyłącznie u dzieci - CHO-KLAT [146]. Dostępne są także skale HRQoL nieswoiste dla hemofilii, jak np. EQ-5D, SF-36 i SF-12. Znaczenie oceny jakości życia jako ważnego narzędzia oceny skuteczności terapii chorych na hemofilię w tym m.in. długoterminowej profilaktyki krwawień, podkreślił Aledort w artykule opublikowanym w Haemophilia [140].

\section{Dodatkowe uwagi o strategii leczenia krwawień u chorych na hemofilię}

O ile krwawienia zagrażające życiu lub związane z silnym bólem powinny być zawsze leczone w warunkach szpitalnych, to większość wylewów krwi do stawów i mięśni może być leczona w warunkach domowych. W warunkach domowych może być także prowadzona pierwotna, wtórna, trzeciorzędowa i krótkoterminowa profilaktyka. Podawanie koncentratu FVIII lub FIX w domu określa się mianem leczenia domowego.

Opieka nad chorym na hemofilię powinna być sprawowana w ośrodkach leczenia hemofilii (Haemophilia Treatment Centres; HTC), które dysponują doświadczonym zespołem lekarskim, mają odpowiednią bazę laboratoryjną oraz dostęp do koncentratów czynników krzepnięcia. Najtrudniejsze przypadki, wymagające trudno dostępnych badań diagnostycznych i zastosowania leczenia wykraczającego poza możliwości HTC, powinny być kierowane do ośrodków referencyjnych leczenia hemofilii (Haemophilia Comprehensive Treatment Centres; HCTC).

Opieka nad chorym na hemofilię w HTC i HCTC nie ogranicza się do wydawania koncentratów czynników krzepnięcia do domu oraz ich wstrzykiwania na miejscu w przypadku ostrych krwawień. W ramach tej opieki należy m.in. regularnie oceniać stan narządu ruchu, przeprowadzać badania przesiewowe w kierunku inhibitora FVIII/FIX, monitorować wirusy przenoszone drogą krwi i produktów krwiopochodnych, leczyć powikłania samej skazy (np. zapalenie błony maziowej stawu, artropatię hemofilową), jak również walczyć z powikłaniami leczenia substytucyjnego (np. inhibitorem, wirusowym zapaleniem wątroby). Taka pełna opieka nad chorym na hemofilię wymaga współpracy HCTC z lekarzami innych specjalności, m.in. ortopedą, chirurgiem, specjalistą chorób zakaźnych, genetykiem, stomatologiem, także z psychologiem. Bardzo ważne jest instruowanie rodziców chorego dziecka, a później samego pacjenta o konieczności dbania o dostęp do żył obwodowych oraz nauczenie chorego samodzielnego wykonywania iniekcji dożylnych. U najmniejszych dzieci nierzadko konieczne jest założenie cewnika do żyły centralnej.

Każdemu pacjentowi $\mathrm{z}$ wrodzoną skazą krwotoczną należy wydać legitymację, w której zawarte są informacje, m.in. na temat rodzaju wykrytej skazy i zalecanych leków hemostatycznych. W legitymacji należy podać adres i numer telefonu ośrodka sprawującego opiekę nad chorym. Pacjenci lub rodzice pacjentów winni prowadzić rejestr epizodów krwotocznych i wstrzyknięć koncentratów. Rejestr taki pozostaje do wglądu pracowników HTC i HCTC, w których także prowadzi się rejestry koncentratów wydawanych pacjentom. 
Dzieci chore na hemofilię powinny chodzić do szkoły razem ze swoimi rówieśnikami. Najlepiej, jeśli koncentrat czynnika VIII lub IX jest przechowywany w szkole (dostarczony przez rodziców), gdyż w razie krwawienia lub urazu będzie szybko wstrzyknięty przez samego pacjenta lub pielęgniarkę. Jeżeli koncentrat nie może być przechowywany w szkole, w przypadku krwawienia lub urazu nauczyciel musi natychmiast skontaktować się z rodzicami i/lub ośrodkiem leczenia hemofilii, pod opieką którego pozostaje chłopiec chory na hemofilię. Dziecko chore na hemofilię może uczestniczyć w zajęciach wychowania fizycznego, pod warunkiem, że ćwiczenia są dostosowane do jego możliwości, tzn. nie grożą poważnymi urazami. Chory na hemofilię może uczestniczyć w wycieczkach szkolnych, przy czym rano $\mathrm{w}$ dniu wycieczki powinien otrzymać profilaktyczne wstrzyknięcie koncentratu czynnika VIII lub IX. Jeśli wycieczka trwa dłużej niż 1 dzień, należy wziąć ze sobą odpowiedni zapas koncentratu. Tylko w wyjątkowych sytuacjach, kiedy chory na hemofilię często opuszcza lekcje z powodu wylewów krwi, należy wprowadzić czasowe lub stałe nauczanie indywidualne w domu pacjenta.

\section{Wytyczne długoterminowej profilaktyki krwawień w hemofilii A i B}

1. U każdego pacjenta $\mathrm{z}$ ciężką hemofilią $\mathrm{A}$ lub B należy dążyć do zastosowania pierwotnej profilaktyki krwawień.

2. U każdego pacjenta $\mathrm{z}$ ciężką hemofilią A lub B, u którego nie zastosowano pierwotnej profilaktyki krwawień, należy dążyć do zastosowania profilaktyki wtórnej.

3. U każdego chorego na ciężką hemofilię A lub B $\mathrm{z}$ artropatią hemofilową, należy rozważyć zastosowanie trzeciorzędowej profilaktyki krwawień.

4. U części pacjentów objętych długoterminową profilaktyką krwawień, u których nie występują żadne samoistne krwawienia i których fenotyp krwotoczny określa się jako łagodny, można rozważyć zakończenie regularnego wstrzykiwania koncentratu niedoborowego czynnika krzepnięcia z chwilą osiągnięcia dojrzałości fizycznej. U pacjentów takich należy stosować okresową profilaktykę krwawień w sytuacjach zwiększonej aktywności fizycznej, kiedy ryzyko wystąpienia krwawień zwiększa się.

5. Jeśli po zakończeniu długoterminowej profilaktyki zaczynają pojawiać się krwawienia do stawów lub o innym umiejscowieniu, należy powrócić do regularnego wstrzykiwania koncentratu niedoborowego czynnika krzepnięcia. Powrót do długoterminowej profilaktyki jest szczególnie wskazany, gdy krwawienia uniemożliwiają kontynuowanie edukacji lub podjęcie pracy zawodowej.

6. Dane z piśmiennictwa nie pozwalają na określenie optymalnych dawek FVIII i FIX w ramach długoterminowej profilaktyki. Za najbardziej właściwe uważa się: a. w hemofilii A: podawanie FVIII w dawce 25-50 IU/kg 3 razy w tygodniu lub co drugi dzień,

b. w hemofilii B: podawanie FIX w dawce 25-50 IU/kg 2 razy w tygodniu (ze względu na różnice właściwości farmakokinetycznych pdFIX i rFIX, dawki rFIX mogą być większe niż pdFIX).

c. U części pacjentów dobry efekt kliniczny osiąga się po zastosowaniu mniejszych dawek i/lub wydłużając odstępy między iniekcjami. Jednakże część pacjentów będzie wymagała większych dawek lub ich częstszego podawania. (Sposób oceny skuteczności programu profilaktyki scharakteryzowano w punkcie 12).

7. Koncentrat niedoborowego czynnika krzepnięcia powinien być podawany rano, a nie wieczorem przed snem (szczyt aktywności wstrzykniętego czynnika powinien przypadać w ciągu dnia).

8. Jeśli w trakcie stosowania długoterminowej profilaktyki pojawiają się krwawienia (breakthrough bleeding), należy rozważyć zmianę schematu profilaktyki (np. zmniejszenie odstępów między wstrzyknięciami) albo zastosowanie dodatkowych wstrzyknięć niedoborowego czynnika krzepnięcia, np. przed okresami zwiększonej aktywności fizycznej.

9. Krwawienia występujące w okresie profilaktyki leczy się $\mathrm{w}$ taki sam sposób jak krwawienia u pacjentów nieobjętych profilaktyką. Częste krwawienia w trakcie długoterminowej profilaktyki świadczą o braku skuteczności zastosowanej formy terapii i są wskazaniem do modyfikacji schematu profilaktycznego. Dodatkowo, należy w takiej sytuacji upewnić się, że nie doszło do pojawienia się inhibitora niedoborowego czynnika krzepnięcia.

10. Za najbardziej właściwą formę długoterminowej profilaktyki uważa się profilaktykę dostosowaną do indywidualnych potrzeb pacjenta, które wynikają z właściwości farmakokinetycznych niedoborowego czynnika krzepnięcia oraz wieku, dostępu do żył, trybu życia i aktywności fizycznej danego pacjenta. Sposób prowadzenia długoterminowej profilaktyki może ulegać modyfikacjom w przypadku zmian ww. parametrów.

11. Decyzję o rozpoczęciu pierwotnej lub wtórnej profilaktyki, wyborze dawki FVIII lub FIX, założeniu cewnika do centralnej żyły - podejmuje doświadczony klinicysta z ośrodka leczenia hemofilii.

12. W czasie stosowania pierwotnej i wtórnej profilaktyki pacjenci powinni być poddawani regularnym (nie rzadziej niż co 6-12 miesięcy) badaniom w ośrodkach leczenia hemofilii w celu oceny skuteczności i bezpieczeństwa stosowanego leczenia. W tym celu należy:

a. Oceniać stan narządu ruchu badaniem fizykalnym; zaleca się stosowanie skali HJHS.

b. Notować wszystkie epizody krwawień w trakcie stosowania profilaktyki oraz analizować ich potencjalne przyczyny tak, aby modyfikując schemat profilaktyki, można było skuteczniej im zapobiegać. 
c. Oceniać stosowanie się pacjenta (rodziców pacjenta) do wymogów schematu profilaktyki. Nieprzestrzeganie zasad profilaktyki może być przyczyną jej nieskuteczności.

d. Okresowo oceniać najniższą aktywność niedoborowego czynnika krzepnięcia w osoczu pacjenta poddawanego długoterminowej profilaktyce. Występowanie krwawień i stwierdzenie aktywności niedoborowego czynnika krzepnięcia <1 IU/dl jest wskazaniem do modyfikacji programu profilaktyki.

e. Rozważyć okresową ocenę stanu narządu ruchu metodami radiologicznymi (MRI w celu poszukiwania niewielkich zmian zwyrodnieniowych; rtg u pacjentów z jawną klinicznie artropatią).

13. Nowoczesne leczenie hemofilii, niezależnie od tego, czy polega na profilaktyce, czy na stosowaniu koncentratów w trybie „na żądanie”, opiera się na terapii domowej. Początkowo rodzice, a następnie sami pacjenci powinni nabyć umiejętności wykonywania dożylnych wstrzyknięć koncentratów czynników krzepnięcia.

14. W przypadku często nawracających krwawień do określonego stawu lub mięśnia u pacjenta $z$ hemofilią A lub B nieobjętego pierwotną, wtórną ani trzeciorzędową profilaktyką należy zastosować przez kilka tygodni lub miesięcy regularne wstrzyknięcia FVIII lub FIX w celu zahamowania krwawień. W okresie krótkoterminowej profilaktyki należy stosować fizjoterapię, która przyspiesza powrót do zdrowia. Dodatkowo należy poinstruować pacjenta, że optymalnym postępowaniem może być rozpoczęcie długoterminowej profilaktyki krwawień.

15. U każdego pacjenta $\mathrm{z}$ ciężką hemofilią $\mathrm{A}$ lub $\mathrm{B}$, który przebył krwawienie zagrażające życiu (np. do centralnego układu nerwowego), należy rozważyć bezterminową profilaktykę $\mathrm{z}$ zastosowaniem koncentratu FVIII lub FIX.

16. $\mathrm{Z}$ chwilą wprowadzenia do lecznictwa w Polsce koncentratów czynników krzepnięcia o przedłużonym działaniu, Grupa ds. Hemostazy PTHiT ogłosi swoje stanowisko w sprawie ich wykorzystania w długoterminowej profilaktyce krwawień u chorych na hemofilię A i B.

\section{Dodatkowe uwagi na temat postępowania w określonych rodzajach krwawień}

Dawkowanie koncentratów czynników krzepnięcia w różnych sytuacjach klinicznych przedstawiono w tabeli III. Należy pamiętać, że koncentraty FVIII, FIX (także DDAVP) powinny być wstrzyknięte jak najszybciej po wystąpieniu krwawienia [147]. Pacjent z krwawieniem niepoddającym się leczeniu w warunkach domowych, zagrażającym życiu, wiążącym się z silnym bólem bądź urazem, o dużym nasileniu, a zwłaszcza lokalizującym się w obrębie głowy i szyi, klatki piersiowej i jamy brzusznej - musi być hospitalizowany. Leczenie substytucyjne ciężkich krwawień należy monitorować oznaczeniami aktywności FVIII lub FIX w osoczu pacjenta. W przypadku słabej reakcji klinicznej na leczenie substytucyjne zawsze należy przeprowadzić badania w kierunku inhibitora FVIII lub FIX. U pacjentów ze skazami krwotocznymi zaleca się unikanie zastrzyków domięśniowych i stosowania leków upośledzających hemostazę, w tym leków antyagregacyjnych i przeciwkrzepliwych. Należy jednak podkreślić, że pojawienie się chorób współistniejących, np. układu sercowo-naczyniowego może spowodować konieczność zastosowania leków przeciwzakrzepowych u chorego na hemofilię. Zagadnienie to omówiono dokładniej w dalszej części niniejszych wytycznych.

\section{Ostre krwawienie do stawu}

Jeśli krwawienie nie ustępuje w ciągu 12-24 h od zastosowania leczenia substytucyjnego (1-2 dawki koncentratu), pacjent powinien zostać zbadany przez lekarza. W pierwszej fazie krwawienia zajęta kończyna powinna być odciążona [148, 149]. Od dekad wskazywano na dobroczynny wpływ okładów z lodu aplikowanych na okolicę stawu dotkniętego krwawieniem w celu obkurczenia naczyń krwionośnych i ograniczenia napływu krwi do przestrzeni stawowej. Odciążenie kończyny (Rest, czyli odpoczynek), stosowanie schładzających kompresów (Ice, czyli lód) wraz z unieruchomieniem bandażem uciskowym (Compression, czyli ucisk) kończyny dotkniętej wylewem krwi i jej uniesieniem (Elevation) zwykło się określać jako R.I.C.E. W ostatnim czasie zaczęto jednak podważać zasadność stosowania lodu, albowiem obniżanie temperatury ciała negatywnie wpływa na proces krzepnięcia krwi i może prowadzić nawet do nasilenia krwawienia (niska temperatura wykazuje jedynie działanie przeciwbólowe) [150]. Przeciwbólowo można zastosować COX-2 inhibitory, paracetamol, a w szczególnych przypadkach leki narkotyczne, przy czym spośród tych ostatnich lekiem pierwszego wyboru jest zazwyczaj słaby opioid tramadol (zasady stosowania leków przeciwbólowych omówiono poniżej). Fizjoterapia powinna zostać wdrożona z chwilą ustępowania bólu i obrzęku. Jeśli krwawienie nie ustępuje w ciągu 48-72 h, czemu towarzyszy utrzymujący się ból i obrzęk, można rozważyć aspirację krwi ze stawu pod osłoną leczenia substytucyjnego. Po aspiracji staw musi być całkowicie unieruchomiony, a aktywność FVIII i FIX utrzymywana na poziomie 40-60 IU/dl przez kolejne 48-72 h. Nakłucie aspiracyjne jest przeciwwskazane w przypadku zakażenia skóry nad zajętym stawem. W każdym przypadku krwawienia do stawu niereagującego na leczenie substytucyjne należy wykonać badanie w kierunku inhibitora FVIII lub FIX. Zasady oceny skuteczności leczenia ostrych krwawień do stawów przedstawiono w tabeli $\mathrm{V}$.

\section{Krwawienie do mięśni}

Najgroźniejsze są wylewy krwi, wynikiem których są krwiaki uciskające na naczynia krwionośne i nerwy [151]. Szczególne znaczenie ma prawidłowe rozpoznanie wylewu krwi do prawego mięśnia biodrowo-lędźwiowego, którego objawy imitują zapalenie wyrostka robaczkowego. W przeciwieństwie do ostrego zapalenia wyrostka robaczkowego, wylew krwi o tej 
Tabela V - Ocena skuteczności leczenia ostrych krwawień do stawów i mięśni

Table V - Assessment of treatment of acute joint and muscle bleeds

\begin{tabular}{|c|c|}
\hline $\begin{array}{l}\text { Ocena skuteczności } \\
\text { leczenia substytucyjnego }\end{array}$ & Definicja \\
\hline Doskonała & $\begin{array}{l}\text { Całkowite ustąpienie bólu w ciągu około } 8 \mathrm{~h} \text { od wstrzyknięcia koncentratu i/lub całkowite ustąpienie } \\
\text { objawów krwawienia po pierwszym wstrzyknięciu koncentratu bez konieczności kolejnych } \\
\text { wstrzyknięć koncentratu (w celu opanowania dolegliwości związanych z tym krwawieniem) w ciągu } \\
\text { pierwszych } 72 \text { h od wystąpienia krwawienia. }\end{array}$ \\
\hline Dobra & $\begin{array}{l}\text { Wyraźne zmniejszenie bólu i/lub wyraźne zmniejszenie objawów krwawienia w ciągu } 8 \text { h od } \\
\text { wstrzyknięcia koncentratu niedoborowego czynnika krzepnięcia, ale bez dodatkowego wstrzyknięcia } \\
\text { koncentratu w ciągu pierwszych } 72 \text { h od wystąpienia krwawienia nie jest możliwe całkowite } \\
\text { ustąpienie dolegliwości związanych z tym krwawieniem. }\end{array}$ \\
\hline Umiarkowana & $\begin{array}{l}\text { Nieznaczne zmniejszenie bólu i/lub nieznaczne zmniejszenie objawów krwawienia w ciągu } 8 \mathrm{~h} \text { od } \\
\text { wstrzyknięcia koncentratu niedoborowego czynnika krzepnięcia; pomimo dodatkowych wstrzyknięć } \\
\text { koncentratu w ciągu pierwszych } 72 \text { h od wystąpienia krwawienia, nie ustępują całkowicie dolegliwości } \\
\text { związane z krwawieniem. }\end{array}$ \\
\hline Słaba & $\begin{array}{l}\text { Brak poprawy lub minimalna poprawa bądź pogorszenie stanu w ciągu } 8 \text { h od wstrzyknięcia } \\
\text { koncentratu. }\end{array}$ \\
\hline
\end{tabular}

Jeśli dodatkowe wstrzyknięcie(a) koncentratu w ciągu pierwszych $72 \mathrm{~h}$ od krwawienia mają na celu jedynie podtrzymanie korzystnego efektu hemostatycznego pierwszego wstrzyknięcia, to nie zmienia to oceny skuteczności leczenia.

lokalizacji leczy się zachowawczo (substytucja czynnika krzepnięcia). Pomocne w rozpoznaniu krwiaków jest badanie ultrasonograficzne, niekiedy wskazane jest wykonanie tomografii komputerowej (CT). Obok wstrzyknięć czynników krzepnięcia (często przez wiele dni), stosuje się także leki przeciwbólowe, okłady z lodu, a przy zajęciu mięśni kończyn obowiązuje zasada ich odciążania i uniesienia oraz rozpoczynania fizjoterapii z chwilą opanowania krwawienia. Zasady oceny skuteczności leczenia ostrych krwawień do mięśni przedstawiono w tabeli $\mathrm{V}$.

\section{Krwawienie do centralnego układu nerwowego/postępowanie po urazie głowy}

W przypadku podejrzenia krwawienia do centralnego układu nerwowego (CUN) obowiązuje zasada - najpierw lecz, potem diagnozuj. Urazy głowy należy leczyć substytucyjnie tak samo intensywnie jak wylewy krwi do CUN, chyba że badania obrazowe (CT, rezonans magnetyczny - MRI) wykluczają obecność ostrego krwawienia do mózgu lub rdzenia kręgowego. Pacjent $\mathrm{z}$ podejrzeniem krwawienia do CUN musi być leczony w warunkach szpitalnych. Silne bóle głowy są często pierwszym objawem krwawienia do CUN u pacjentów $\mathrm{z}$ hemofilią. U każdego pacjenta po przebytym krwawieniu do CUN należy rozważyć bezterminową wtórną profilaktykę krwawień z zastosowaniem koncentratów FVIII lub FIX $[35,151]$.

\section{Krwawienie do szyi i do gardła}

Jest to stan zagrożenia życia (ryzyko niedrożności dróg oddechowych) [151]. Pierwszą czynnością jest wstrzyknięcie niedoborowego czynnika krzepnięcia. Leczenie należy zawsze prowadzić w warunkach szpitalnych, często na oddziale intensywnej opieki medycznej. U pacjentów z ciężko przebiegającym ostrym zapaleniem migdałków są wskazania do profilaktyki z zastosowaniem koncentratu FVIII lub FIX.

\section{Ostry krwotok z górnego odcinka przewodu pokarmowego}

Leczenie należy zawsze prowadzić w warunkach szpitalnych. Zaraz po wstrzyknięciu odpowiedniej dawki niedoborowego czynnika krzepnięcia należy rozważyć wykonanie badania endoskopowego, które ma charakter nie tylko diagnostyczny, ale także leczniczy, gdyż umożliwia wstrzyknięcie substancji obliterującej uszkodzone naczynie krwionośne [152]. Bardzo często oprócz leczenia substytucyjnego włącza się lek hamujący fibrynolizę (kwas traneksamowy).

\section{Uraz lub krwawienie do gałki ocznej}

Pierwszą czynnością jest wstrzyknięcie niedoborowego czynnika krzepnięcia. Zawsze konieczna jest hospitalizacja i jak najszybsze uzyskanie opinii konsultanta okulisty o najbardziej właściwym sposobie dalszego postępowania.

\section{Krwiomocz}

Jeśli nie towarzyszy mu ból, postępowanie ogranicza się do leżenia w łóżku i intensywnego nawadniania (3 litry $/ \mathrm{m}^{2}$ powierzchni ciała) przez $48 \mathrm{~h}$. Jeśli krwiomocz jest bardzo intensywny lub towarzyszy mu ból, należy rozpocząć leczenie substytucyjne. Jeśli krwiomocz nawraca lub stale występuje krwinkomocz, konieczna staje się konsultacja urologa i/lub nefrologa.

\section{Krwawienie ze błony śluzowej jamy ustnej i krwawienie $\mathrm{z}$ nosa}

Często ten rodzaj krwawień udaje się opanować za pomocą samego leku antyfibrynolitycznego, stosowanego systemowo [153]. W przypadku krwawienia w obrębie jamy ustnej, antyfibrynolityk można zastosować także miejscowo w postaci roztworu do płukania. Jeśli takie postępowania jest nieskuteczne, wstrzykuje się koncentrat niedoborowego czynnika krzepnięcia krwi. W krwawieniach z nosa ponadto 
stosuje się miejscowo spongostan nasączony trombiną oraz ucisk ze strony krwawiącego przewodu nosowego. Jeśli krwawienia nawracają, pacjent powinien być skonsultowany przez stomatologa i/lub laryngologa. Przyczyną powtarzających się krwawień z nosa u chorego na hemofilię może być nadciśnienie tętnicze krwi lub nieprawidłowy splot naczyniowy.

\section{Rany i otarcia skóry}

Tylko głębokie zranienia wymagają leczenia substytucyjnego i interwencji chirurgicznej. W pozostałych przypadkach należy odkazić ranę lub otarcie i zastosować zwykły plaster $\mathrm{z}$ jałowym opatrunkiem.

\section{Złamania kości}

Zawsze wymagają leczenia szpitalnego [154]. Pierwszą czynnością jest wstrzyknięcie niedoborowego czynnika krzepnięcia. Wybór dalszego postępowania należy do ortopedy, który, zależnie od rodzaju i lokalizacji złamania, decyduje o leczeniu operacyjnym lub zachowawczym. Należy unikać długotrwałego unieruchomienia i jak najszybciej rozpoczynać fizjoterapię.

\section{Ciąża i poród u nosicielki hemofilii}

Opiekę nad nosicielką hemofilii w ciąży powinien sprawować zespół doświadczonych klinicystów złożony z ginekologa, hematologa i genetyka [18]. W okresie ciąży nosicielki hemofilii A bardzo rzadko doznają powikłań krwotocznych, gdyż w miarę rozwoju ciąży aktywność czynnika VIII wzrasta. Jeśli jednak wystąpią krwawienia, a aktywność FVIII lub FIX będzie mniejsza niż $50 \mathrm{IU} / \mathrm{dl}$, to należy zastosować - najlepiej rekombinowany koncentrat FVIII lub FIX; w przypadku nosicielstwa hemofilii A - można zastosować (z dużą ostrożnością) DDAVP [46, 48, 155, 156]. Poród powinien odbywać się w ośrodku, który ma dostęp do laboratorium wykonującego oznaczenia aktywności czynników krzepnięcia. W okresie porodu FVIII:C lub FIX: C należy utrzymywać $\geq 50 \mathrm{IU} / \mathrm{dl}$ (w hemofilii A można stosować desmopresynę lub koncentrat FVIII, a w hemofilii B - koncentrat FIX). Przy takiej aktywności FVIII i FIX można bezpiecznie wykonać nakłucie lędźwiowe w celu zastosowania znieczulenia. W okresie połogu - do zagojenia rany - aktywność FVIII i FIX powinna być także utrzymywana $\geq 50 \mathrm{IU} / \mathrm{dl}$. Sposób porodu (drogą naturalną us cięciem cesarskim) powinien być ustalony w oparciu o czynniki położnicze i hematologiczne [48, 155]. Należy jednak dołożyć wszelkich starań, aby zapobiec konieczności porodu zabiegowego (użycia kleszczy położniczych lub próżnociągu), ponieważ zwiększa to ryzyko urazu noworodka. Podobnie przedłużający się drugi okres porodu zwiększa ryzyko urazu dziecka. Przeciwwskazane są również inwazyjne metody monitorowania płodu. Zaleca się, aby badanie aktywności czynników krzepnięcia wykonać z krwi pępowinowej. Noworodki płci męskiej z podejrzeniem hemofilii lub z rozpoznaną hemofilią powinny mieć wykonane przezciemiączkowe badanie ultrasonograficzne (USG) przed wypisem do domu i w razie stwierdzenia krwawienia natychmiast leczone koncentratem czynnika VIII lub IX. W przypadku wystąpienia objawów krwotoku śródczaszkowego należy natychmiast zastosować koncentrat FVIII lub FIX, a następnie wykonać badanie USG [157].

\section{Postępowanie w okresie okołooperacyjnym}

Zabiegi operacyjne $\mathrm{u}$ chorych na hemofilię powinny być przeprowadzone w HTC lub HCTC, które mają dostęp do odpowiednich koncentratów czynników krzepnięcia i odpowiednią bazę laboratoryjną. Przed operacją należy zawsze przeprowadzić badanie w kierunku inhibitora FVIII lub FIX. W dniu operacji koncentrat wstrzykuje się na ogół około 1$2 \mathrm{~h}$ przed zabiegiem, przy czym 30 minut po jego wstrzyknięciu należy pobrać od pacjenta próbkę krwi, w której oznacza się aktywność FVIII lub FIX w celu upewnienia się, że osiągnięty został poziom hemostatyczny (FVIII:C $\geq 80 \mathrm{IU} / \mathrm{dl}$, FIX:C $\geq 60 \mathrm{IU} / \mathrm{dl})$. W tabeli III przedstawiono orientacyjne dawkowanie koncentratu FVIII i koncentratu FIX u pacjentów poddawanych zabiegom ekstrakcji zębów i dużym operacjom chirurgicznym [18, 158]. W hemofilii A kolejne dawki koncentratu FVIII najczęściej podaje się w odstępach $12 \mathrm{~h}$, a w hemofilii B - koncentrat FIX podaje się początkowo w odstępach $12 \mathrm{~h}$, a od 3-4 doby po operacji - 18-24 h. Wynika to $\mathrm{z}$ dłuższego końcowego okresu półtrwania FIX w porównaniu z FVIII. Laboratoryjne monitorowanie leczenia polega na codziennym pomiarze aktywności FVIII lub FIX w próbce krwi pobranej na około $1 \mathrm{~h}$ przed planowanym czasem podania kolejnej dawki koncentratu. W ten sposób monitoruje się najniższą dobową aktywność FVIII lub FIX (trough level) i w oparciu o jej wartość koryguje dawki koncentratu. Bolusy dożylne nie są jedynym sposobem podawania koncentratów czynników krzepnięcia. Jeżeli wiadomo, że pacjent będzie leczony substytucyjne przez $>3$ dni, można rozważyć zastosowanie ciągłego wlewu dożylnego czynnika krzepnięcia VIII lub IX, zgodnie z aktualnymi wytycznymi [159, 160]. Ciągły wlew dożylny czynników krzepnięcia stosuje się nie tylko do osłony dużych operacji chirurgicznych, ale także w przypadku krwawień zagrażających życiu. W tabeli VI przedstawiono zasady oceny skuteczności profilaktyki okołooperacyjnej z zastosowaniem koncentratów FVIII i FIX u chorych na hemofilię, odpowiednio A i B.

\section{Powikłania hemofilii i powikłania leczenia substytucyjnego}

Powikłaniami samej choroby są: przewlekłe zapalenie błony maziowej, artropatia hemofilowa i pseudoguzy hemofilowe. Powikłaniami leczenia substytucyjnego hemofilii są: inhibitory FVIII i FIX oraz zakażenia drobnoustrojami przenoszonymi przez krew.

\section{Przewlekłe zapalenie błony maziowej}

W wyniku powtarzających się krwawień do stawu dochodzi do przewlekłego zapalenia i przerostu błony maziowej stawu [161-163]. Staw jest obrzęknięty, choć zazwyczaj niebolesny. Przerost błony maziowej stawu można potwierdzić badaniem ultrasonograficznym i MRI [164]. MRI lub radiogram przeglądowy (RTG) stawu pozwala ocenić stopień zniszcze- 
Tabela VI - Ocena skuteczności profilaktyki okolooperacyjnej z zastosowaniem koncentratów niedoborowego czynnika krzepnięcia u chorych na hemofilię

Table VI - Assessment of peri-operative efficacy of replacement therapy with clotting factor concentrates in patients with haemophilia Ocena skuteczności leczenia
substytucyjnego

Doskonała

Dobra

Umiarkowana

Słaba/brak
Okołooperacyjna utrata krwi zbliżona $( \pm 10 \%)$ do utraty krwi obserwowanej u pacjentów bez hemofilii poddawanych tym samym operacjom. Leczenie substytucyjne zgodne z zaplanowanym przed operacją schematem i bez konieczności pozaplanowych wstrzyknięć koncentratu FVIII/FIX. Zapotrzebowanie na transfuzję składników krwi zgodne z przewidywaniami.

Okołooperacyjna utrata krwi nieco większa (o 10-25\%) od utraty krwi obserwowanej u pacjentów bez hemofilii poddawanych tym samym operacjom. niemniej, znaczenie kliniczne nadmiernej utraty krwi jest małe i nie wymaga korygowania schematu wstrzyknięć koncentratu zaplanowanego przed operacją. Zapotrzebowanie na transfuzję składników krwi zgodne z przewidywaniami.

Okołooperacyjna utrata krwi większa o $25-50 \%$ od utraty krwi obserwowanej u pacjentów bez hemofilii poddawanych tym samym operacjom. Zaplanowany przed operacją schemat wstrzyknięć koncentratu wymaga modyfikacji - konieczne są dodatkowe wstrzyknięcia koncentratu. Zapotrzebowanie na transfuzję składników krwi większe (ale mniej niż dwukrotnie) od przewidywanego przed operacją. Nadmierne krwawienie jest związane $\mathrm{z}$ hemofilią.

Okołooperacyjna utrata krwi większa o $>50 \%$ od utraty krwi obserwowanej u pacjentów bez hemofilii poddawanych tym samym operacjom. Zaplanowany przed operacją schemat wstrzyknięć koncentratu wymaga istotnej modyfikacji - konieczne są dodatkowe wstrzyknięcia koncentratu. Zapotrzebowanie na transfuzję składników krwi ponad dwukrotnie większe od przewidywanego przed operacją. Mogą być niezbędne inne działania zmierzające do zahamowania nadmiernego krwawienia. Powikłania krwotoczne są ewidentnie związane $\mathrm{z}$ hemofilią. nia chrząstki i kości. Pacjentom z przewlekłym zapaleniem błony maziowej stawu zaleca się ćwiczenia fizyczne (w osłonie koncentratu czynnika krzepnięcia) w celu wzmocnienia siły mięśniowej, COX-2 inhibitory, niekiedy wstrzykuje się do stawu długodziałające kortykosteroidy. Jeśli zapaleniu błony maziowej towarzyszą często powtarzające się wylewy krwi do stawu, należy rozważyć wykonanie chirurgicznego zabiegu usunięcia błony maziowej, czyli synowektomii. Znacznie częściej niż synowektomię chirurgiczną stosuje się obecnie synowektomię izotopową, polegającą na wstrzyknięciu do stawu izotopu emitującego promieniowanie beta (fosfor-32 lub itr-90). Opis sposobu przeprowadzenia zabiegu można znaleźć w piśmiennictwie [165, 166].

\section{Artropatia}

Utrzymujące się przewlekłe zapalenie błony maziowej oraz powtarzające się wylewy krwi do stawu prowadzą do nieodwracalnego zniszczenia chrzęstnych i kostnych struktur stawu. Postępują procesy włóknienia, z czasem dochodzi do znacznego ograniczenia ruchomości zaatakowanego stawu, jego deformacji, a w konsekwencji zaników sąsiadujących grup mięśniowych - zjawisk określanych mianem artropatii hemofilowej [148].

Celem leczenia pacjenta $\mathrm{z}$ artropatią jest usprawnienie narządu ruchu i walka $\mathrm{z}$ bólem, która często wymaga stosowania leków narkotycznych. U części chorych poprawę uzyskuje się fizjoterapią, prowadzoną pod osłoną leczenia substytucyjnego. Stosuje się także, z różnym powodzeniem, stabilizatory stawów. Jeśli leczenie zachowawcze jest nieskuteczne, należy rozważyć interwencję chirurgiczną, która w zależności od tego, który staw jest zajęty, może polegać na: artroskopowym uwolnieniu wewnątrz-stawowych zrostów, zabiegu na okołostawowych tkankach miękkich w celu uwolnienia przykurczu zgięciowego, korekcyjnej osteotomii, artrodezie oraz wszczepieniu endoprotezy stawowej $[149,167]$.
Prawidłowa opieka nad chorym na hemofilię $\mathrm{z}$ artropatią hemofilową wymaga ścisłej współpracy hematologa $\mathrm{z}$ ortopedą i specjalistą w zakresie fizjoterapii [168, 169]. Zabiegi operacyjne z zakresu ortopedii powinny być przeprowadzane w referencyjnych ośrodkach leczenia hemofilii lub w ośrodkach ortopedycznych stale i ściśle współpracujących z HCTC.

\section{Pseudoguzy}

Są wynikiem źle leczonych lub nieleczonych krwawień do tkanek miękkich znajdujących się w bezpośrednim sąsiedztwie kości [170, 171]. Powiększający się krwiak (pseudoguz) uciska na nerwy, naczynia i prowadzi do destrukcji kości. Najczęściej pseudoguz rozwija się w miednicy i udzie. Do potwierdzenia rozpoznania wykorzystuje się techniki obrazowe (RTG, USG, CT, MRI). O ile w przypadku małego pseudoguza intensyfikacja leczenia substytucyjnego może doprowadzić do zatrzymania jego progresji, o tyle w przypadku psedoguzów o dużych rozmiarach zawsze należy rozważyć możliwość jego chirurgicznego usunięcia. Zabieg taki powinien być przeprowadzany w referencyjnym ośrodku leczenia hemofilii.

\section{Inhibitory}

Zasady diagnostyki i leczenia hemofilii A i B powikłanej inhibitorami FVIII i FIX są omówione w II części zaleceń postępowania we wrodzonych skazach krwotocznych na tle niedoboru czynników krzepnięcia.

\section{Wirusy i inne cząstki zakaźne przenoszone drogą krwi i preparatów krwiopochodnych}

Ryzyko zakażenia HCV, HBV i HIV przez współcześnie stosowane koncentraty czynników krzepnięcia jest praktycznie zerowe. Jednakże, jak wykazała przeprowadzana kilka 
lat temu analiza, około $80 \%$ polskich chorych na ciężką hemofilię A i B urodzonych przed 1991 rokiem, było zakażonych HCV, a około 10\% - HBV (HIV był obecny u 1 spośród 172 przebadanych pacjentów) [172]. W celu zapewnienia optymalnej opieki nad chorymi na hemofilię zakażonymi wyżej wymienionymi wirusami, ośrodek leczenia hemofilii powinien współpracować ze specjalistami z zakresu chorób zakaźnych i chorób wątroby.

U każdego pacjenta zakażonego HCV i/lub HBV należy rozważyć włączenie leczenia przeciwwirusowego. Zasadniczo, leczenie ww. zakażeń wirusowych u chorych na hemofilię nie różni się od leczenia tych zakażeń w innych populacjach pacjentów. Wraz z wprowadzeniem do lecznictwa schematu leczenia HCV za pomocą pegylowanego interferonu (PegIFN) i rybawiryny, odsetek pacjentów, u których udaje się wyeliminować HCV znacznie się zwiększył $[173,174]$. Kombinacja PegIFN + rybawiryna jest zalecana w pierwszej linii u pacjentów zakażonych HCV. U pacjentów z genotypem $1 \mathrm{HCV}$ nieodpowiadających na to leczenie powinno się zastosować nowe leki, z grupy leków wykazujących bezpośrednie działanie antywirusowe (direct acting antiviral; DAA), czyli boceprevir i telaprevir [175, 176]. Obserwacje ostatnich lat wskazują, że nowe leki anty-HCV w kombinacji z PegIFN i rybawiryną zwiększają szansę wyeliminowania genotypu 1 HCV u 70-80\% zakażonych pacjentów. Telaprevir i boceprevir wykazują słabą aktywność antywirusową wobec innych genotypów HCV niż genotyp 1. Kolejnym lekiem o silnym działaniu antywirusowym wobec genotypu 1a i 1b HCV jest inhibitor HCV NS5A ledipasvir. Lek ten $\mathrm{w}$ połączeniu $\mathrm{z}$ sofosbuvirem (inhibitor HCV NS5B) wykazał dużą skuteczność w eliminowaniu HCV genotyp $1 \mathrm{u}$ pacjentów nieodpowiadających na leczenie z zastosowaniem PegIFN [177]. Z kolei inny inhibitor HCV NS5A - daclatasvir, w połączeniu z sofosbuvirem skutecznie eliminował HCV genotyp 1, 2 i 3 u pacjentów, którzy nie odpowiedzieli uprzednio na leczenie z zastosowaniem telapreviru i bocepreviru [178]. Lekami stosowanymi w walce z HBV są PegIFN oraz analogi nukleoz(t)ydów będące inhibitorami wirusowej polimerazy (lamivudine, adefovir, telbivudine, entecavir i tenofovir) [175].

Zwykle decyzja o zakwalifikowaniu pacjenta $\mathrm{z}$ hemofilią do leczenia przeciwwirusowego nie opiera się na wyniku badania histopatologicznego wątroby [179, 180]. Zamiast biopsji wątroby, do oceny przebiegu choroby wątroby wykorzystuje się metody nieinwazyjne, tj. elastografię wątroby (Fibroscan) w powiązaniu z oznaczaniem wybranych markerów biochemicznych (fibrotest) [176]. Jeśli jednak metody nieinwazyjne nie dostarczają niezbędnych informacji do podjęcia decyzji terapeutycznych, może zajść konieczność wykonania biopsji wątroby. Przykładem takiej sytuacji jest stwierdzenie obecności HCV RNA u pacjenta z prawidłową aktywnością aminotransferaz, a także w przypadku kwalifikacji do transplantacji wątroby oraz w procesie obserwacji pod kątem pierwotnego raka wątrobowokomórkowego (hepatocellular carcinoma; HCC). Pacjent poddawany biopsji wątroby wymaga kilkudniowego leczenia substytucyjnego w celu prewencji krwawień. Wytyczne brytyjskie [176] zalecają w takiej sytuacji osiągnięcie następującej aktywności FVIII lub FIX w osoczu pacjenta poddawanego biopsji wątroby: 1) przed zabiegiem $100 \mathrm{IU} / \mathrm{dl}$
2) $12 \mathrm{~h}$ po biopsji: pomiar aktywności niedoborowego czynnika krzepnięcia i wstrzyknięcie dawki zapewniającej utrzymanie aktywności na poziomie $100 \mathrm{IU} / \mathrm{dl}$

3) $24 \mathrm{~h}$ po biopsji: pomiar aktywności niedoborowego czynnika krzepnięcia i wstrzyknięcie dawki zapewniającej utrzymanie aktywności na poziomie $100 \mathrm{IU} / \mathrm{dl}$

4) 48 h po biopsji: pomiar aktywności niedoborowego czynnika krzepnięcia i wstrzyknięcie dawki zapewniającej utrzymanie aktywności na poziomie $100 \mathrm{IU} / \mathrm{dl}$

U każdego pacjenta $\mathrm{z}$ wywiadem wieloletniego zakażenia HCV i/lub HBV należy regularnie (co 6-12 miesięcy) monitorować biochemiczne parametry funkcji wątroby, stężenie $\alpha$-fetoproteiny i oceniać ultrasonograficznie strukturę wątroby (zwiększone ryzyko HCC) [181]. Badaniem z wyboru w rozpoznawaniu żylaków przełyku jest gastrofiberoskopia. U pacjentów z zaawansowanym włóknieniem lub marskością wątroby zaleca się powtarzanie oceny ultrasonograficznej narządu co 6 miesięcy, zaś gastrofiberoskopię należy przeprowadzać co 3 lata [176]. Sposób leczenia HCC zależy od umiejscowienia i rozległości procesu nowotworowego Radykalne metody leczenia to resekcja guza i transplantacja wątroby, zaś postępowanie paliatywne to wstrzyknięcia alkoholu do guza, radioablacja i przeztętnicza embolizacja. Wskazania do transplantacji wątroby u chorych na hemofilię zakażonych wirusami hepatotropowymi nie różnią się od wskazań do tego zabiegu w innych grupach pacjentów zakażonych tymi wirusami. W Polsce przeprowadzono co najmniej pięć transplantacji wątroby u chorych na ciężką hemofilię A (dane nieopublikowane, K. Zawilska, J. Windyga). Wszystkie zakończyły się powodzeniem. Nadto, co najmniej w dwóch przypadkach - zgodnie z przewidywaniami - aktywność FVIII w osoczu biorców narządu znormalizowała się, czyli pacjenci zostali wyleczeni z hemofilii.

Każdy pacjent $z$ hemofilią, który nie jest zakażony HBV, powinien zostać zaszczepiony przeciwko temu wirusowi. Obecnie przeważa opinia, że chorych na hemofilię powinno się także obowiązkowo szczepić przeciwko wirusowi zapalenia wątroby typu A (HAV). Należy podkreślić, że szczepienia dzieci chorych na hemofilię powinny być prowadzone zgodnie $\mathrm{z}$ kalendarzem szczepień. Konieczne jest jedynie zwrócenie uwagi, że u chorych na skazy krwotoczne należy unikać wstrzyknięć domięśniowych. Dlatego chorym na hemofilię szczepionki podaje się drogą podskórną. Markery zakażenia HCV, HBV i HIV powinny być sprawdzane raz w roku u każdego pacjenta $\mathrm{z}$ hemofilią $[182,183]$.

Spośród wielu cząstek zakaźnych, które - teoretycznie mogą zostać przeniesione przez koncentraty (głównie osoczopochodne) czynników krzepnięcia, pragniemy zwrócić uwagę na dwie: ludzki parvowirus B19 (B19) i priony. Parvowirus B19 (podobnie do HAV) należy do wirusów bezotoczkowych i dlatego poddaje się znacznie trudniej procedurom inaktywacji bądź eliminacji wirusów, stosowanych w procesie produkcyjnym koncentratów czynników krzepnięcia w porównaniu z wirusami otoczkowymi (HCV, HBV, HIV). Parvowirus B19 był wykrywany w takich preparatach osoczopochodnych, jak koncentraty FVIII i FIX, albuminy i immunoglobuliny $[67,68]$. Jak dotąd, nie opisano objawów zakażenia wywołanych B19 przeniesionym przez koncentraty czynników krzepnięcia. Brak chorobotwórczości B19 w tych przypadkach tłumaczy się (współ)obecnością 
Tabela VII - Zasady leczenia bólu u chorych na hemofilię

Table VII - Principles of pain management in patients with haemophilia

\begin{tabular}{ll} 
Pierwszy wybór & Paracetamol (500-1000 mg/dawkę, maks. 4-6 x dziennie) \\
& $\downarrow$ Jeśli brak skuteczności \\
& Inhibitory COX-2 (np. celekoksyb, meloksykam, nimesulid i inne) \\
& $\downarrow$ lub \\
& Paracetamol + kodeina (10-20 mg/dawkę) (3-4 razy dziennie) \\
& $\downarrow$ lub \\
& Paracetamol + tramadol (50-100 mg/dawkę) (3-4 razy dziennie) \\
& Morfina: lepiej stosować preparaty o powolnym uwalnianiu (dawka początkowa 20 mg co 12 h), \\
& a preparaty szybko działające podawać w dawce 10 mg, nie częściej niż co 6 h. Jeśli preparaty szybko \\
Trzeci wybór & działające są stosowane częsiej niż 4 razy na dobę, należy zwiększyć udział w leczeniu bólu preparatów \\
& o powolnym uwalnianiu. \\
\hline stosować z dużą ostrożnością u pacjentów z upośledzoną funkcją nerek i nadciśnieniem; \\
coX - cyklooksygenaza
\end{tabular}

w koncentratach neutralizujących przeciwciał anty-B19. Niemniej, obecność B19 w osoczopochodnych koncentratach czynników krzepnięcia oznacza, że ryzyko przeniesienia przez te koncentraty różnych, w tym być może bardziej chorobotwórczych niż B19 cząstek zakaźnych, jest realne.

Priony - to tzw. białkowe cząstki zakaźne, zbudowane z polimerów utworzonych przez powszechnie występujące w różnych organizmach białka, które stają się groźne z chwilą utraty swojej prawidłowej, naturalnej konformacji [184]. Białka prionowe oznacza się skrótem PrP, zaś białka prionowe o zmienionej konformacji - PrP ${ }^{\mathrm{sc}}$.

Priony powodują tzw. wariant choroby Creutzfeldta i Jakoba (variant Creutzfeldt-Jakob disease; vCJD). Pierwszy przypadek vCJD opisano w Wielkiej Brytanii w 1996 r. [185]. Do 2004 r., wszystkie rozpoznane przypadki vCJD wiązano ze spożywaniem mięsa bydła chorującego na gąbczastą enecefalopatię (bovine spongiform encephalopathy; BSE) [186]. Jednak w ostatniej dekadzie opisano w Wielkiej Brytanii cztery przypadki wariantu choroby Creutzfeldta i Jakoba, najprawdopodobniej spowodowanej transfuzją koncentratu krwinek czerwonych od dawców, u których po pewnym czasie rozwinęła się vCJD [186]. Co więcej, osocze od zakażonych dawców było wykorzystywane w Wielkiej Brytanii do produkcji pdFVIII i pdFIX w latach 80. i 90. XX wieku. W 2010 r. doniesiono o wykryciu prionów w śledzionie chorego na hemofilię A w trakcie autopsji [187]. Choć pacjent ten nie miał za życia żadnych objawów vCJD, autorzy doniesienia stanęli na stanowisku, że jest to pierwszy przypadek przeniesienia prionów przez koncentraty pdFVIII. W zgodnej opinii ekspertów, ryzyko przeniesienia prionów przez osoczopochodne koncentraty czynników krzepnięcia, zwłaszcza w ilości grożącej rozwojem vCJD jest bardzo małe [184, 186]. Niemniej, biorąc pod uwagę, że wciąż nie są dostępne testy laboratoryjne służące wykrywaniu prionów, najlepszym sposobem zminimalizowania ryzyka rozwoju vCJD jest stosowanie koncentratów rekombinowanych czynników krzepnięcia.

\section{Farmakologiczne leczenie bólu związanego $z$ hemofilią i jej powikłaniami}

Ostry i przewlekły ból jest częstym problemem u chorych na hemofilię. Może on wynikać $\mathrm{z}$ wylewu krwi do stawu, mięśnia, z rozwoju zmian zwyrodnieniowych w stawach, może być związany z przeprowadzonym zabiegiem operacyjnym albo częstymi iniekcjami dożylnymi. W tym ostatnim przypadku, głównie u dzieci, stosuje się miejscowo leki znieczulające w postaci kremu lub spreju. W pozostałych przypadkach często sięga się po leki przeciwbólowe działające systemowo [18, 188]. W tabeli VII przedstawiono zasady postępowania $\mathrm{w}$ walce $\mathrm{z}$ bólem $\mathrm{u}$ chorych na hemofilię, czyli tzw. drabinę analgetyczną. Należy podkreślić, że u chorych na hemofilię należy unikać leków przeciwbólowych zwiększających ryzyko krwawień oraz iniekcji domięśniowych, które mogą być powikłane bolesnymi krwiakami. Choć niesteroidowe leki przeciwzapalne (nonsteroidal anti-inflammatory drugs; NSAID) niebędące selektywnymi inhibitorami COX-2 mogą zwiększać ryzyko krwawień, to jak wykazało niedawno opublikowane badanie, w wielu europejskich ośrodkach leczenia hemofilii NSAID są dość powszechnie stosowane [189]. Wynika to zapewne z większej skuteczności nieselektywnych inhibitorów COX$2 \mathrm{w}$ porównaniu $\mathrm{z}$ selektywnymi inhibitorami COX-2 u części pacjentów z hemofilią. Najczęściej spośród NSAID wybierane są ibuprofen i diklofenak [189]. Warto także przypomnieć, że leczenie bólu nie ogranicza się do stosowania preparatów farmakologicznych, ale obejmuje także fizjoterapię, psychoterapię, a w przypadku zaawansowanej artropatii - leczenie chirurgiczne.

\section{Postępowanie w chorobach wspólistniejących związanych z procesem starzenia}

Skuteczna prewencja i leczenie krwawień, w tym krwawień zagrażających życiu, prowadzi do wydłużenia życia chorych na hemofilię. Dłuższe życie pacjentów z hemofilią prowadzi z kolei do rozwoju chorób typowych dla procesu starzenia, których przed kilkoma dekadami nie obserwowano z powodu przedwczesnych zgonów chorych na hemofilię wywołanych ciężkimi krwawieniami [190-193]. W tabeli VIII wymieniono choroby i stany kliniczne obserwowane w starzejącej się populacji pacjentów z hemofilią. Wpływ starzenia na strategię leczenia hemofilii jest bardzo duży. Wystarczy powiedzieć, że bezwzględnie przeciwwskazane w przeszłości u chorych na hemofilię leki przeciwpłytkowe i antykoagulanty obecnie mogą być stosowane np. 
Tabela VIII - Choroby i stany kliniczne obserwowane w przebiegu starzenia się chorych na hemofilię Table VIII - Disorders and clinical issues observed in ageing haemophilia patients

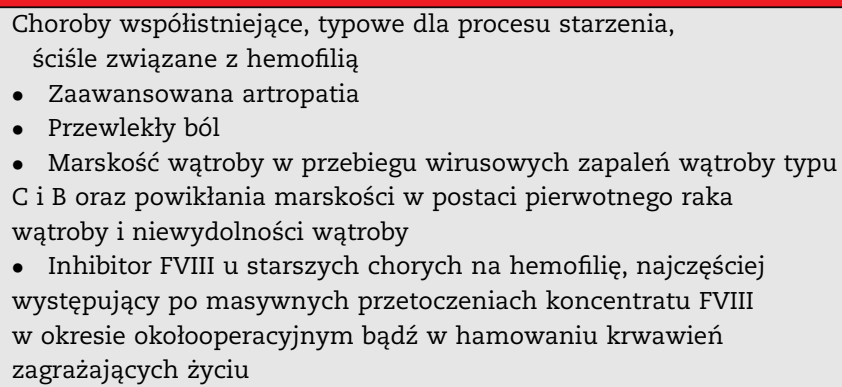$$
\text { zagrajacych życiu }
$$

Choroby współistniejące, typowe dla procesu starzenia

- Choroby układu sercowo-naczyniowego

- Nowotwory złośliwe

- Osteoporoza

- Upadki i złamania kości

- Przerost gruczołu krokowego

- Otyłość

- Nadciśnienie tętnicze

- Niewydolność nerek

- Cukrzyca

- Depresja

- Zaburzenia erekcji

- Zaćma w przypadku wystąpienia migotania przedsionków albo zawału serca [194, 195].

W licznych artykułach opublikowanych w ostatnich latach przedstawiono możliwości leczenia chorób związanych z procesem starzenia w populacji chorych na hemofilię [196-203]. Artykuły te przedstawiają nie tyle wytyczne oparte na dowodach naukowych, co sugestie wynikające z doświadczenia ekspertów i ekstrapolacji danych uzyskanych w leczeniu określonych jednostek chorobowych w innych grupach pacjentów. Zachęcamy do zapoznania się z tymi artykułami, zaś poniżej przedstawiamy nasze sugestie odnośnie do omawianego zagadnienia.

Sugestie odnośnie do leczenia chorób związanych $\mathrm{z}$ procesem starzenia $\mathrm{u}$ chorych na hemofilię

1. Chorzy na hemofilię w starszym wieku powinni być monitorowani pod kątem możliwości rozwoju chorób typowych dla procesu starzenia, z których najważniejsze, to:

a. choroby układu sercowo-naczyniowego

b. nowotwory złośliwe

c. osteoporoza

2. W odniesieniu do chorób układu sercowo-naczyniowego należy zwrócić szczególną uwagę na:

a. Sprawdzanie stężenia cholesterolu i glukozy we krwi (LDL-cholesterol $<2,5 \mathrm{mmol} / \mathrm{l}$, stężenie glukozy na czczo $<6,1 \mathrm{mmol} / \mathrm{l})$ i w przypadku stwierdzenia odchyleń od normy wdrożenie odpowiedniego postępowania terapeutycznego (podskórne wstrzyknięcia insuliny nie powodują powikłań krwotocznych).

b. Edukację w zakresie szkodliwości palenia tytoniu i działania zmierzające do redukcji masy ciała. Otyłość u starszych osób z hemofilią może wynikać m.in. z małej aktywności fizycznej spowodowanej zaawansowaną artropatią. Należy zachęcać do podejmowania aktywności fizycznej (np. sesje kinezyterapii w osłonie hemostatycznej koncentratu czynnika krzepnięcia). c. Pacjenci $z$ hemofilią są narażeni w większym stopniu na nadciśnienie tętnicze niż mężczyźni ogólnej populacji. Biorąc pod uwagę ryzyko poważnych zdarzeń krwotocznych w tej populacji chorych, należy skutecznie zwalczać nadciśnienie tętnicze. Stosuje się w tym celu takie same leki, jak w innych grupach pacjentów i zaleca utrzymywanie wartości skurczowego ciśnienia tętniczego krwi poniżej $140 \mathrm{mmHg}$, a rozkurczowego - poniżej $90 \mathrm{mmHg}$.

d. Leczenie ostrych zespołów wieńcowych u chorych na hemofilię odbywa się według zbliżonych zasad jak w innych populacjach pacjentów. Chorym na hemofilię można podawać leki przeciwpłytkowe, przeciwkrzepliwe i trombolityczne oraz można wykonać u nich przezskórną interwencję sercową (percutaneous cardiac intervention; PCI), ale należy pamiętać o konieczności zastosowania odpowiedniej osłony hemostatycznej za pomocą koncentratu niedoborowego czynnika krzepnięcia pod kontrolą aktywności tego czynnika w osoczu. Należy przy tym unikać nadmiernej aktywności uzupełnianego czynnika krzepnięcia (nie przekraczać $80 \mathrm{IU} / \mathrm{dl})$.

e. Podczas wykonywania PCI u chorego na hemofilię zalecany jest dostęp przez tętnicę promieniową, a nie udową (mniejsze ryzyko miejscowych powikłań krwotocznych).

f. Wykonując stentowanie naczyń wieńcowych, wybiera się stenty metalowe, a nie powlekane, dzięki czemu można skrócić czas stosowania podwójnej terapii przeciwpłytkowej.

g. Uważa się, że stosując podwójną terapię przeciwpłytkową u chorych na hemofilię, należy utrzymywać aktywność FVIII lub FIX w osoczu $\geq 25 \mathrm{IU} / \mathrm{dl}$.

h. Nie stosuje się leków przeciwpłytkowych u chorych na ciężką hemofilię, jeśli równocześnie nie podaje się profilaktycznie koncentratu niedoborowego czynnika krzepnięcia krwi.

i. Przy stosowaniu terapeutycznych dawek heparyn lub antagonistów witaminy $\mathrm{K}$ (np. 
u pacjenta z migotaniem przedsionków) należy utrzymywać aktywność niedoborowego czynnika krzepnięcia $>25 \mathrm{IU} / \mathrm{dl}$.

UWAGA: stosowanie leków przeciwzakrzepowych, a tym bardziej trombolitycznych u pacjentów $z$ hemofilią jest obarczone dużym ryzykiem powikłań krwotocznych. Dlatego nadzór nad tym leczeniem powinien sprawować ekspert z ośrodka leczenia hemofilii, który dostosowuje strategię postępowania do indywidualnego przypadku.

3. W odniesieniu do nowotworów złośliwych zwracamy uwagę na konieczność skryningu pod kątem najczęściej występujących nowotworów, zgodnie ze schematami skryningu obowiązującymi dla mężczyzn ogólnej populacji. Sposób leczenia chorych na hemofilię z chorobą nowotworową nie różni się od sposobu leczenia innych grup chorych dotkniętych tym samym typem nowotworu. Profilaktyka przeciwkrwotoczna $\mathrm{z}$ zastosowaniem niedoborowego czynnika krzepnięcia powinna być stosowana w sytuacjach zwiększonego zagrożenia krwawieniami, $\mathrm{np}$. w okresie okołooperacyjnym lub jako osłona inwazyjnych zabiegów diagnostycznych. Decyzja o zastosowaniu farmakologicznej tromboprofilaktyki (np. w okresie okołooperacyjnym) należy do eksperta $\mathrm{z}$ ośrodka leczenia hemofilii $\mathrm{w}$ porozumieniu z ekspertem $\mathrm{z}$ ośrodka onkologicznego.

4. W odniesieniu do osteoporozy zwracamy uwagę na fakt, że powikłanie to występuje istotnie częściej w grupie chorych na hemofilię niż u mężczyzn ogólnej populacji. Przeciwdziałanie osteoporozie polega na promowaniu aktywności fizycznej. Postępowanie farmakologiczne polega na uzupełnianiu wapnia i witaminy D oraz stosowaniu bisfosfonianów lub denosumabu. Leczenie powinno odbywać się w porozumieniu z ekspertem z ośrodka leczenia osteoporozy.

\section{Wkład autorów/Authors' contributions}

Według kolejności.

\section{Konflikt interesu/Conflict of interest}

JW - uczestniczył w badaniach klinicznych i otrzymywał wynagrodzenie za wygłoszone wykłady od firm Baxalta, Baxter, Bayer, CSL Behring, Biogen Idec, Novo Nordisk, Octapharma, Pfizer, SOBI. KC - uczestniczył w badaniach klinicznych i otrzymywał wynagrodzenie za wygłoszone wykłady i udzielone konsultacje od firm Baxter, BPL, Novo Nordisk, Octapharma, Wyeth, ZLB Behring. AK - uczestniczyła $\mathrm{w}$ badaniach klinicznych i otrzymywała wynagrodzenie za wygłoszone wykłady i udzielone konsultacje od firm Baxter, Bayer Schering Pharma, CSL Behring, Grifols, Novo Nordisk, Octapharma, Wyeth, Pfizer. MŁ - otrzymywała wynagrodzenie za wygłoszone wykłady i udzielone konsultacje od firm Baxter, Bayer, Grifols, Novo Nordisk. AM - uczestniczył w badaniach klinicznych i otrzymywał wynagrodzenie za wygłoszone wykłady i udzielone konsultacje od firm Baxter, BPL, Novo Nordisk. MP-D - otrzymywała wynagrodzenie za wygłoszone wykłady i udzielone konsultacje od firm Baxter, CSL Behring i Novo Nordisk oraz uczestniczyła w badaniach klinicznych firm BPL, CSL Behring, Pfizer. JT - otrzymywał wynagrodzenie za wygłoszone wykłady od firmy Baxter i Novo Nordisk. TU - otrzymywał wynagrodzenie za wygłoszone wykłady od firmy Baxalta, Baxter i Novo Nordisk i Pfizer. JZ - uczestniczyła w badaniach klinicznych i otrzymywała wynagrodzenie za wygłoszone wykłady i udzielone konsultacje od firm Baxter, Bayer Schering Pharma, BPL, CSL Behring, Grifols, Novo Nordisk. KZ otrzymywała wynagrodzenie za konsultacje i wygłoszone wykłady od firm Baxter, Bayer, CSL Behring, Novo Nordisk, Pfizer, a także uczestniczyła w badaniu klinicznym firmy Baxter. AU, JM, JP-P - nie zgłasza potencjalnego konfliktu interesów w związku z tą publikacją.

\section{Finansowanie/Financial support}

Nie występuje.

\section{Etyka/Ethics}

Treści przedstawione $\mathrm{w}$ artykule są zgodne $\mathrm{z}$ zasadami Deklaracji Helsińskiej, dyrektywami EU oraz ujednoliconymi wymaganiami dla czasopism biomedycznych.

\section{P IŚ M I E N N I C T W O/R E FERENCES}

[1] Windyga J, Chojnowski K, Klukowska A, et al. Polskie zalecenia postępowania we wrodzonych skazach krwotocznych na tle niedoboru czynników krzepnięcia. Część I: Zasady postępowania w hemofilii A i B. Acta Haematol Pol 2008;39:537-564.

[2] Windyga J. Diagnostyka laboratoryjna zaburzeń hemostazy. W: Mariańskiej B, Fabijańskiej-Mitek J, Windygi J, reds. Badania laboratoryjne w hematologii. Podręcznik dla słuchaczy studiów medycznych pod. Warszawa. Wyd. Lek. PZWL; 2003. p. 192-225.

[3] White II GC, Rosendaal F, Aledort LM, Lusher JM, Rothschild C, Ingerslev J, On behalf of factor VIII and factor IX Subcommittee. Definitions in haemophilia. Recommendations of the Scientific Subcommittee on Factor VIII and Factor IX of the Scientific and Standardization Committee of the International Society on Thrombosis and Haemostasis. Thromb Haemost 2001;85:560.

[4] Hollestelle MJ, Thinnes T, Crain K. Tissue distribution of factor VIII gene expression in vivo: a closer look. Thromb Haemost 2001;86:855-861.

[5] Gitschier J, Wood WI, Goralka TM, et al. Characterization of the human factor VIII gene. Nature 1984;312:326-330. 
[6] Bolton-Maggs PHB, Pasi JK. Haemophilias A and B. Lancet 2003;361:1801-1809.

[7] Lakich D, Kazazian Jr HH, Antonarakis SE, Gitschier J. Inversions disrupting the factor VIII gene are a common cause of severe haemophilia A. Nat Genet 1993;5:236-241.

[8] Rossiter JP, Young M, Kimberland ML. Factor VIII gene inversions causing severe haemophilia A originate almost exclusively in male germ cells. Hum Mol Genet 1994;3:1035-1039.

[9] Bagnall RD, Waseem N, Green PM, Giannelli F. Recurrent inversion braking intron 1 of the factor VIII gene is a frequent cause of severe haemophilia A. Blood 2002;99:168-174.

[10] Kaufman RJ. Cellular processing of factors VIII and IX. W: Lee CA, Berntorp EE, Hoots KW, reds. Textbook of Hemophilia. Oxford: Blackwell Publishing; 2005. p. 5-12.

[11] Kurachi K, Davie EW. Isolation and characterization of a cDNA coding for human factor IX. Proc Natl Acad Sci 1982;79:6461-6464.

[12] Green PM. Hemophilia B - molecular basis. W: Lee CA, Berntorp EE, Hoots KW, reds. Textbook of Hemophilia. Oxford: Blackwell Publishing; 2005. p. 91-96.

[13] Goodeve AC. Hemophilia B: molecular pathogenesis and mutation analysis. J Thromb Haemost 2015;13: 1184-1195.

[14] Reitsma PH, Bertina RM, Ploos van Amstel JK. The putative factor IX gene promoter in hemophilia B Leyden. Blood 1988;72:1074-1076.

[15] Hildyard C, Keeling D. Effect of age on factor IX levels in symptomatic carriers of Haemophila B Leyden. Br J Haematol 2015;169:448-449.

[16] Rimmer EK, Seftel MD, Israels SJ, Houston DS. Unintended benefit of anabolic steroid use in hemophilia B leiden. Am J Hematol 2012;87:122-123.

[17] Plug I, Mauser-Bunschoten Indyga P, Brocker-Vriends AHJT. Bleeding in carriers of hemophilia. Blood 2006;108:52-56.

[18] Srivastava A, Brewer AK, Mauser-Bunschoten EP, et al. Treatment guidelines Working Group on behalf of the World Federation of Hemophilia. Haemophilia 2013;19:1-47.

[19] Stonebraker JS, Bolton-Maggs PH, Soucie JM, Walker I, Brooker M. A study of variations in the reported haemophilia A prevalence around the world. Haemophilia 2010;16:20-32.

[20] Windyga J, Łopaciuk S, Stefańska E, et al. Hemofilia i pokrewne skazy krwotoczne w Polsce. Pol Arch Med Wew 2004;112:1197-1202.

[21] Blanchette VS, Key NS, Ljung LR, Manco-Johnson MJ, van den Berg HM, Srivastava A. Subcommittee on Factor VIII, Factor IX and Rare Coagulation Disorders of the Scientific and Standardization Committee of the International Society on Thrombosis and Hemostasis. Definitions in hemophilia: communication from the SSC of the ISTH. J Thromb Haemost 2014;12:1935-1939.

[22] Santagostino E, Mancuso ME, Tripodi A, et al. Severe hemophilia with mild bleeding phenotype: molecular characterization and global coagulation profile. J Thromb Haemost 2010;8:737-743.

[23] Nagel K, Walker I, Decker K, Chan AK, Pai MK. Comparing bleed frequency and factor concentrate use between haemophilia A and B patients. Haemophilia 2011;17:872-874

[24] Darby SC, Kan SW, Spooner RJ, et al. Mortality rates, life expectancy, and causes of death in people with hemophilia A or B in the United Kingdom who were not infected with HIV. Blood 2007;110:815-825.

[25] Vyas S, Enockson C, Hernandez L, Valentino LA. Towards personalizing haemophilia care: using the Haemophilia
Severity Score to assess 178 patients in a single institution. Haemophilia 2014;20:9-14.

[26] Clausen N, Petrini P, Claeyssens-Donadel S, Gouw SC, Liesner R, PedNet and Research of Determinants of Inhibitor development (RODIN) Study Group. Similar bleeding phenotype in young children with haemophilia A or B: a cohort study. Haemophilia 2014;20:747-755.

[27] Pollmann H, Richter H, Ringkamp H, Jurgens H. When are children diagnosed as having severe haemophilia and when do they start to bleed?. A 10-year single-centre PUP study. Eur J Pediatr 1999;158(supl. 3):166-170.

[28] Klukowska A. Pierwsze objawy hemofilii u dzieci. Ped Pol 1990;65:9-13.

[29] Kulkarni R, Soucie JM, Lusher J, et al. Haemophilia Treatment Center Network Investigators. Sites of initial bleeding episodes, mode of delivery and age of diagnosis in babies with haemophilia diagnosed before the age of 2 years: a report from The Centers for Disease Control and Prevention's (CDC) Universal Data Collection (UDC) project. Haemophilia 2009;15:1281-1290.

[30] Windyga J, Stefańska E, Łopaciuk S, Juszyński A, Woźniak D, Strzelecki D. Stan narządu ruchu w wybranej grupie chorych na ciężką hemofilię. Pol Arch Med Wew 2005;113 (6):562-569.

[31] Klukowska A, Czyrny Z, Łaguna P, Brzewski M, Serafin-Król MA, Rokicka-Milewska R. Correlation between clinical, radiological and ultrasonographical image of knee joints in children with haemophilia. Haemophilia 2001; 7:286-292.

[32] Donadel-Claeyssens S, on behalf of the European Paediatric Network for Haemophilia Management. Current co-ordinated activities of the PEDNET (European Paediatric Network for Haemophilia Management). Haemophilia 2006;12:124-127.

[33] Ota S, McLimont M, Carcao MD, et al. Definitions for haemophilia prophylaxis and its outcomes: the Canadian Consensus Study. Haemophilia 2007;13:12-20.

[34] Szczepanik AB, Zaleska M, Wiszniewski A, et al. Helicobacter pylori infection in patients with haemophilia in Poland: prevalence and risk of upper gastrointestinal bleeding. Haemophilia 2005;11:376-379.

[35] Ljung RCR. Intracranial haemorrhage in haemophilia A and B. British Journal of Haematology 2008;140:378-384.

[36] Klukowska A, Gazda H, Szczepanik E. Odległe wyniki leczenia wylewów śródczaszkowych u dzieci chorych na wrodzone osoczowe skazy krwotoczne. Ped Pol 1988;43:312-318.

[37] White B, Ryan C. Work-up of a bleeding adult. W: Lee CA, Berntorp EE, Hoots KW, reds. Textbook of Hemophilia. Oxford: Blackwell Publishing; 2005. p. 13-18.

[38] Blanchette VS, Kahr WHA. Work-up of a bleeding child. W: Lee CA, Berntorp EE, Hoots KW, reds. Textbook of Hemophilia. Oxford: Blackwell Publishing; 2005. p. 112-119.

[39] Barrowclifee TW. Standardization of FVIII \& FIX assays. Haemophilia 2003;9:397-402.

[40] Verbruggen B, Meijer P, Novakova I, van Heerde W. Diagnosis of factor VIII deficiency. Haemophilia 2008;14 (supl. 3):76-82.

[41] Barrowclifee TW. Monitoring haemophilia severity and treatment: new or old laboratory tests? Haemophilia 2004;10(supl. 4):109-114.

[42] Colvin BT, Astermark J, Fischer K, et al., For the Interdisciplinary Working Group. European principles of haemophilia care. Haemophilia 2008;14:361-374.

[43] Oldenburg J, Ananyeva NM, Saenko EL. Molecular basis of haemophilia A. Haemophilia 2004;10(supl. 4): 133-139. 
[44] Miller R. Counselling about diagnosis and inheritance of genetic bleeding disorders: haemophilia A and B. Haemophilia 1999;5:77-83.

[45] Ross J. Perspectives of haemophilia carriers. Haemophilia 2000;6(supl. 1):41-45.

[46] Kadir RA, Davies J, Winikoff R, et al. Pregnancy complications and obstetric care in women with inherited bleeding disorders. Haemophilia 2013;19(Suppl 4):1-10.

[47] Bustamante-Aragones A, Rodriguez de Alba M, GonzalezGonzalez C, et al. Foetal sex determination in maternal blood from the seventh week of gestation and its role in diagnosing haemophilia in the foetuses of female carriers. Haemophilia 2008;14:593-598.

[48] Chi C, Lee CA, Shiltagh N, Khan A, Pollard D, Kadir RA. Pregnancy in carriers of haemophilia. Haemophilia 2008;14:56-64.

[49] Tsui NB, Kadir RA, Chan KC, et al. Noninvasive prenatal diagnosis of hemophilia by microfluidics digital PCR analysis of maternal plasma DNA. Blood 2011;117:3684-3691.

[50] Mackie I, Cooper P, Lawrie A, Kitchen S, Gray E, Laffan M, on behalf of british committee for standards in haematology. Guidelines on the laboratory aspects of assays used in haemostasis and thrombosis. Int Jnl Lab Hem 2013;35:1-13.

[51] Trossaërt M, Boisseau P, Quemener A, et al. Prevalence, biological phenotype and genotype in moderate/mild hemophilia A with discrepancy between one-stage and chromogenic factor VIII activity. J Thromb Haemost 2011;9:524-530.

[52] Cid AR, Calabuig M, Cortina V, et al. One-stage and chromogenic FVIII:C assay discrepancy in mild haemophilia A and the relationship with the mutation and bleeding phenotype. Haemophilia 2008;14:1049-1054.

[53] Potgieter JJ, Damgaard M, Hillarp A. One-stage vs. chromogenic assays in haemophilia A. Eur J Haematol 2015;94(Suppl 77):38-44

[54] Nathwani AC, Tuddenham EG, Rangarajan S, et al. Adenovirus-associated virus vector-mediated gene transfer in hemophilia B. N Engl J Med 2011;365:2357-2365.

[55] Nathwani AC, Reiss UM, Tuddenham EG, et al. Long-term safety and efficacy of factor IX gene therapy in hemophilia B. N Engl J Med 2014;371:1994-2004.

[56] Ohmori T, Mizukami H, Ozawa K, Sakata Y, Nishimura S. New approaches to gene and cell therapy for hemophilia. J Thromb Haemost 2015;13(Suppl 1):S133-S142.

[57] Ofosu FA, Freedman J, Semple JW. Plasma-derived biological medicines used to promote haemostasis. Thromb Haemost 2008;99:851-862.

[58] Mannucci PM, Mancuso ME, Santagostino E. How we choose factor VIII to treat hemophilia. Blood 2012;119:4108-4114.

[59] Giangrande PLF. Products used to treat hemophilia: plasma-derived coagulation factor concentrates. W: Lee CA, Berntorp EE, Hoots WK, reds. Textbook of Hemophilia. Third Edition, Wiley Blackwell; 2014. p. 174-179.

[60] Key NS, Negrier C. Coagulation factor concentrates: past, present, and future. Lancet 2007;370:439-448.

[61] Mannucci PM. Hemophilia: treatment options in the twenty-first century. J Thromb Haemost 2003;1:1349-1355.

[62] Windyga J. Rekombinowane czynniki krzepnięcia krwi. Acta Haematol Pol 2004;35(supl. 1):1-10.

[63] Plug I, van der Bom JG, Peters M, et al. Mortality and causes of death in patients with hemophilia, 1992-2001: a prospective cohort study. J Thromb Haemost 2006;4:510-516.

[64] Tabor E. The epidemiology of virus transmission by plasma derivatives. Clinical studies verifying the lack of transmission of hepatitis B and C viruses and HIV type 1. Transfusion 1999;39:1160-1168.
[65] Azzi A, Morfini M, Mannucci PM. The transfusionassociated transmission of parvovirus B19. Transf Med Rev 1999;13:194-204.

[66] Farrugia A. Evolving perspectives in product safety for hemophilia. Haemophilia 2002;8:236-243.

[67] Dodd RY. Emerging pathogens and their implications for the blood supply and transfusion transmitted infections. Br J Haematol 2012;159:135-142.

[68] Ragni MV, Sherman KE, Jordan JA. Viral pathogens. Haemophilia 2010;16(suppl. 5):40-46.

[69] Pipe SW. Recombinant clotting factors. Thromb Haemost 2008;99:840-850.

[70] Shima M, Yoshioka A. Products used to treat hemophilia: recombinant products. W: Lee CA, Berntorp EE, Hoots WK, reds. Textbook of Hemophilia. Third Edition, Wiley Blackwell; 2014. p. 165-173.

[71] Lusher JM, Arkin S, Abildgaard CF, Schwartz RS. Recombinant factor VIII for the treatment of previously untreated patients with hemophilia A. Safety, efficacy and development of inhibitors. Kogenate Previously Untreated Patients Study Group. N Engl J Med 1993;328:453-459.

[72] Bray GL, Gomperts ED, Courter S, et al. A multicenter study of recombinant factor VIII (recombinate): safety, efficacy, and inhibitor risk in previously untreated patients with hemophilia A. The Recombinate Safety Study. Blood 1994;83:2428-2435.

[73] Mikaelsson M, Oswaldsson U, Jankowski MA. Measurement of factor VIII activity of B-domain deleted recombinant factor VIII. Seminars in Haematol 2001;38:13-23.

[74] White GC, Beebe A, Nielsen B. Recombinant factor IX. Thromb Haemost 1997;78:261-265.

[75] Gouw SC, van der Bom JG, Ljung R, et al., PedNet and RODIN Study Group. Factor VIII products and inhibitor development in severe hemophilia A. N Engl J Med 2013;368:231-239.

[76] Calvez T, Chambost H, Claeyssens-Donadel S, et al. FranceCoag Network. Recombinant factor VIII products and inhibitor development in previously untreated boys with severe hemophilia A. Blood 2014;124:3398-3408.

[77] Collins PW, Palmer BP, Chalmers EA, et al., UK Haemophilia Centre Doctors' Organization. Factor VIII brand and the incidence of factor VIII inhibitors in previously untreated UK children with severe hemophilia A, 2000-2001. Blood 2014;124(23):3389-3397.

[78] van der Bom JG, Gouw SC, Rosendaal FR. Secondgeneration recombinant factor VIII and inhibitor risk: interpretation of RODIN study findings and implications for patients with haemophilia A. Haemophilia 2014;20(2):e171-e174.

[79] Ragni MV. FVIII brand and immunogenicity. Blood 2014;124:3337-3338.

[80] Berntorp E, Iorio A. Reflections on the FranceCoag report on inhibitory antibodies to factor VIII in patients with severe hemophilia A. Blood 2015;125:3816-3817.

[81] DiMinno MND, Marchesini E, Valdre L. Risk of inhibitors in previously untreated patients with hemophilia: a metaanalysis of liyterature studies. Blood 2015;125:3819-3820.

[82] Fischer K, Lassila R, Peyvandi F, et al. EUHASS participants. Inhibitor development in haemophilia according to concentrate. Four-year results from the European Haemophilia Safety Surveillance (EUHASS) project. J Thromb Haemost 2015;113:968-973.

[83] Mannucci PM, Garagiola I. Factor VIII products in haemophilia A: one size fits all? Thromb Haemost 2015;113:958-967.

[84] Björkman S. Pharmacokinetics. W: Lee CA, Berntorp EE, Hoots WK, reds. Textbook of Hemophilia. Third Edition, Wiley Blackwell; 2014. p. 117-122. 
[85] Björkman S. Pharmacokinetics and dose requirements of factor VIII over the age range 3-74 years. Eur J Clin Pharmacol 2009;65:989-998.

[86] Björkman S. Pharmacokinetics of plasma-derived and recombinant factor IX - implications for prophylaxis and on-demand therapy. Haemophilia 2013;19:808-813.

[87] Björkman S, Fokesson A, Berntorp E. In vivo recovery of factor VIII and factor IX: intra- and interindividual variance in clinical setting. Haemophilia 2007;13:2-8.

[88] Collins PW, et al. Implications of coagulation factor VIII and IX pharmacokinetics in the prophylactic treatment of haemophilia. Haemophilia 2011;17:2-10.

[89] Collins PW, et al. Breakthrough bleeding in relations to predicted factor VIII levels in patients receiving prophylaxic treatment for severe haemophilia A. J Thromb Haemost 2009;7:413-420.

[90] Valentino LA. Considerations in individualizing prophylaxis in patients with haemophilia A. Haemophilia 2014;20:607-615.

[91] Reininger AJ, Chehadeh HE. The principles of PK-tailored prophylaxis. Hämostaseologie 2013;33(suppl. 1):S32-S35.

[92] Rickard KA. Guidelines for therapy and optimal dosages of coagulation factors for treatment of bleeding and surgery in haemophilia. Haemophilia 1995;1(supl. 1):8-13.

[93] Kasper CK. Hereditary plasma clotting factor disorders and their management. Haemophilia 2000;6(supl. 1):13-37.

[94] Santagostino E, Mannucci PM, Bonomi AB. Guidelines on replacament therapy for haemophilia and inherited coagulation disorders in Italy. Haemophilia 2000;6:1-10.

[95] Report of a joint WHO/WFH/ISTH meeting. Delivery of treatment for haemophilia. Geneva, Switzerland: World Health Organization; 2002.

[96] Bolton-Maggs PHB, Stobart K, Smyth RL. Evidence-based treatment of haemophilia. Haemophilia 2004;10(supl. 4):20-24.

[97] Morfini M, Marchesini E, Paladino E, Santoro C, Zanon E, Iorio A. Pharmacokinetics of plasma-derived vs. recombinant FVIII concentrates: a comparative study. Haemophilia 2015;21:204-209.

[98] Björkman S. A commentary on the differences in pharmacokinetics between recombinant and plasmaderived factor IX and their implications for dosing. Haemophilia 2011;17:179-184.

[99] Powell JS. Lasting power of new clotting proteins. Hematology 2014;355-363.

[100] Powell JS, Pasi KJ, Ragni MV, et al. B-LONG Investigators. Phase 3 study of recombinant factor IX FC fusion protein in hemophilia B. N Engl J Med 2013;369:2313-2323.

[101] Mahlangu J, Powell JS, Ragni MV, et al., A-LONG Investigators. Phase 3 study of recombinant factor VIII FC fusion protein in severe hemophilia A. Blood 2014 Jan 16;123(3):317-325.

[102] Oldenburg J, Albert T. Novel products for haemostasis current status. Haemophilia 2014;20(suppl. 4):23-28.

[103] Klukowska A, Zawilska K. w imieniu Grupy ds. Hemostazy Polskiego Towarzystwa Hematologów i Transfuzjologów. Koncentraty czynników krzepnięcia o przedłużonym działaniu w leczeniu hemofilii. Acta Haematol Pol 2015;46 (4):299-303.

[104] Castaman G. Desmopressin for the treatment of haemophilia. Haemophilia 2008;14(supl. 1):15-20.

[105] Mannucci PM. Treatment of von Willebrand's disease. N Engl J Med 2004;351:683-694.

[106] Federici AB. The use of desmopressin in von Willebrand disease: the experience of the first 30 years (1977-2007). Haemophilia 2008;14(supl. 1):5-14.

[107] Tengborn L. Fibrinolytic inhibitors in the management of bleeding disorders. World Federation of Haemophilia,
2012, no 42. Publikacja dostępna na stronie internetowej www.wfh.org.

[108] Burnouf T, Radosevich M. Local hemostatic blood products in hemophilia care: fibrin sealant and platelet gel. World Federation of Haemophilia, 2008. Publikacja dostępna na stronie internetowej www.wfh.org.

[109] Schexneider KI. Fibrin sealants in surgical or traumatic hemorrhage. Curr Opin Hematol 2004;11:323-326.

[110] Łaguna P, Klukowska A, Grabowska A, Rokicka-Milewska R. Zastosowanie kleju fibrynowego Tacho-Comb w hamowaniu krwawień po ekstrakcji zębów u dzieci ze skazami krwotocznymi. Ped Pol 1999;74:899-903.

[111] Pipe SW, Valentino LA. Optimizing outcomes for patients with severe haemophilia A. Haemophilia 2007;13 (supl. 4):1-16.

[112] Aledort LM, Haschmeyer RH, Pettersson H. A longitudinal study of orthopaedic outcomes for severe factor-VIIIdeficient haemophiliacs. The Orthopaedic Outcome Study Group. J Intern Med 1994;236:391-399.

[113] Manco-Johnson MJ, Abshire TC, Shapiro AD, et al. Prophylaxis versus Episodic Treatment to Prevent Joint Disease in Boys with Severe Hemophilia. N Eng J Med 2007;357:535-544.

[114] Gringeri A, Lundin B, von Mackensen S, Mantovani L, Mannucci PM, ESPRIT Study Group. A randomized clinical trial of prophylaxis in children with hemophilia A (the ESPRIT Study). J Thromb Haemost 2011;9:700-710.

[115] Ahnstrom J, Berntorp EL, Bjorkman S. A 6-year follow-up of dosing, coagulation factor levels and bleedings in relation to joint status in the prophylactic treatment of haemophilia. Haemophilia 2004;10:689-697.

[116] Berntorp E. Pharmacoeconomics of factor dosing in the haemophilia population. Haemophilia 2006; 12(supl. 4):70-73.

[117] Nilsson IM, Berntorp E, Löfqvist T, Pettersson H. Twentyfive years' experience of prophylactic treatment in severe haemophilia A and B. J Intern Med 1992;232:25-32.

[118] Fisher K, Astermark J, van der Bom JG, et al. Prophylactic treatment for severe haemophilia: comparison of an intermediate-dose to a high-dose regimen. Haemophilia 2002;8:753-760.

[119] Richards M, Williams M, Chalmers E, et al. Paediatric Working Party of the United Kingdom Haemophilia Doctors' Organisation. A United Kingdom Haemophilia Centre Doctors' Organization guideline approved by the British Committee for Standards in Haematology: guideline on the use of prophylactic factor VIII concentrate in children and adults with severe haemophilia $\mathrm{A}$. Br J Haematol 2010;149:498-507.

[120] Biss TT, Chan AK, Blanchette VS, Iwenofu LN, McLimont M, Carcao MD. Association of Hemophilia Clinic Directors of Canada (AHCDC); Canadian Association of Nurses in Hemophilia Care (CANHC). The use of prophylaxis in 2663 children and adults with haemophilia: results of the 2006 Canadian national haemophilia prophylaxis survey. Haemophilia 2008;14:923-930.

[121] Fisher K, Steen Carlsson K, Petrini P, et al. Intermediatedose versus high-dose prophylaxis for severe hemophilia: comparing outcome and costs since the 1970s. Blood 2013;122:1129-1136.

[122] Lofqvist T, Nilsson IM, Berntorp E, Pettersson H. Haemophilia prophylaxis in young patients - a long term follow up. J Intern Med 1997;241:395-400.

[123] van den Berg HM, Fischer K, Mauser-Bunschoten EP, et al. Long-term outcome of individualized prophylactic treatment of children with severe haemophilia. Br J Haematol 2001;112:561-565.

[124] Feldman BM, Pai M, Rivard GE, et al., Association of Hemophilia Clinic Directors of Canada Prophylaxis Study 
Group. Tailored prophylaxis in severe hemophilia A: interim results from the first 5 years of the Canadian Hemophilia Primary Prophylaxis Study. J Thromb Haemost 2006;4:1228-1236.

[125] Kraft J, Blanchette V, Babyn P, et al. Magnetic resonance imaging and joint outcomes in boys with severe hemophilia A treated with tailored primary prophylaxis in Canada. J Thromb Haemost 2012;10:2494-2502.

[126] Shapiro AD, Di Paola J, Cohen A, et al. The safety and efficacy of recombinant human blood coagulation factor IX in previously untreated patients with severe or moderately severe hemophilia B. Blood 2005;105:518-525.

[127] Rocca A, Pizzinelli S, Oliovecchio E, Santagostino E, Rocino A, Iorio A, Italian ad hoc study group. Replacement therapy with recombinant factor IX. A multicentre evaluation of current dosing practices in Italy. Blood Transfus 2011;9:60-69.

[128] Fischer K, van der Bom JG, Mauser-Bunschoten EP, et al. The effects of postponing prophylactic treatment on longterm outcome in patients with severe hemophilia. Blood 2002;99:2337-2341.

[129] Gringeri A, Lambert T, Street A, Aledort L, Adolescent/ Adult Prophylaxis Expert Working Group of the International Prophylaxis Study Group. Tertiary prophylaxis in adults: is there a rationale? Haemophilia 2012;18:722-728.

[130] Manco-Johnson MJ, Kempton CL, Reding MT, et al. Randomized, controlled, parallel-group trial of routine prophylaxis vs. on-demand treatment with sucroseformulated recombinant factor VIII in adults with severe hemophilia A (SPINART). J Thromb Haemost 2013;11:1119-1127.

[131] Valentino LA, Mamonov V, Hellmann A, et al., Prophylaxis Study Group. A randomized comparison of two prophylaxis regimens and a paired comparison of ondemand and prophylaxis treatments in hemophilia A management. J Thromb Haemost 2012;10:359-367.

[132] Windyga J, Lissitchkov T, Stasyshyn O, et al. Haemophilia. Pharmacokinetics, efficacy and safety of BAX326, a novel recombinant factor IX: a prospective, controlled, multicentre phase I/III study in previously treated patients with severe (FIX level $<1 \%$ ) or moderately severe (FIX level $\leq 2 \%$ ) haemophilia B. Haemophilia 2014;20:15-24.

[133] Valentino LA, Rusen L, Elezovic I, Smith LM, Korth-Bradley JM, Rendo P. Multicentre, randomized, open-label study of on-demand treatment with two prophylaxis regimens of recombinant coagulation factor IX in haemophilia B subjects. Haemophilia 2014;20:398-406.

[134] Tagliaferri A, Feola G, Molinari AC, et al., POTTER Study Group. Benefits of prophylaxis versus on-demand treatment in adolescents and adults with severe hemophilia A: the POTTER study. Thromb Haemost 2015;114:35-45.

[135] Collins PW. Personalized prophylaxis. Haemophilia 2012;18(suppl. 4):131-135.

[136] Björkman S. Limited blood sampling for pharmacokinetic dose tailoring of FVIII in the prophylactic treatment of haemophiliaA. Haemophilia 2010;16:597-605.

[137] Björkman S. Population pharmacokinetics of recombinant factor IX: implications for dose tailoring. Haemophilia 2013;19:753-757.

[138] Sheiner LB, Beal S, Rosenberg B, Marathe VV. Forecasting individual pharmacokinetics. Clin Pharmacol Ther 1979;26:294-305.

[139] Gringeri A, Ewenstein B, Reininger A. The burden of bleeding in haemophilia: is one bleed too many? Haemophilia 2014;20:459-463.

[140] Aledort L, Bullinger M, von Mackensen S, Wasserman J, Young NL, Globe D, Health Related Quality of Life
Expert Working Group of the International Prophylaxis Study Group. Why should we care about quality of life in persons with haemophilia? Haemophilia 2012;18: e154-e157.

[141] Oldenburg J. Optimal treatment strategies for hemophilia: achievements and limitations of current prophylactic regimens. Blood 2015;125:2038-2044.

[142] Richards M, Williams M, Chalmers E, et al. Paediatric Working Party of the United Kingdom Haemophilia Doctors' Organisation. A United Kingdom Haemophilia Centre Doctors' Organization guideline approved by the British Committee for Standards in Haematology: guideline on the use of prophylactic factor VIII concentrate in children and adults with severe haemophilia $\mathrm{A}$. Br J Haematol 2010;149:498-507.

[143] Schwartz R, Ljung R, Tedgard U. Various regimens for prophylactic treatment of patients with haemophilia. Eur J Haematol 2015;94(suppl. 77):11-16.

[144] Lundin B, Manco-Johnson ML, Ignas DM, et al., International Prophylaxis Study Group. An MRI scale for assessment of haemophilic arthropathy from the International Prophylaxis Study Group. Haemophilia 2012;18:962-970.

[145] Martinoli C, Della Casa Alberighi O, Di Minno G, et al. Development and definition of a simplified scanning procedure and scoring method for Haemophilia Early Arthropathy Detection with Ultrasound (HEAD-US). Thromb Haemost 2013;109:1170-1179.

[146] Young NL, Bradley CS, Wakefield CD, Barnard D, Blanchette VS, McCusker PJ. How well does the Canadian Haemophilia Outcomes-Kids' Life Assessment Tool (CHOKLAT) measure the quality of life of boys with haemophilia? Pediatr Blood Cancer 2006;47:305-311.

[147] Zawilska K, Windyga J, Łętowska M. Zasady udzielania doraźnej pomocy przeciwkrwotocznej chorym na hemofilie i pokrewne skazy krwotoczne przez lekarzy pogotowia ratunkowego, szpitalnych oddziałów ratunkowych i lekarzy rodzinnych. J Transf Med 2015;8: 78-79.

[148] Lafeber FPJG, Miossec P, Valentino LA. Physiopathology of haemophilic arthropathy. Haemophilia 2008; 14(supl 1):3-9.

[149] Bossard D, Carillon Y, Stieltjes N, et al. Management of haemophilic arthropathy. Haemophilia 2008;14(supl. 1):11-19.

[150] Forsyth AL, Zourikian N, Valentino LA, Rivard GE. The effect of cooling on coagulation and haemostasis: should "Ice" be part of treatment of acute haemarthrosis in haemophilia? Haemophilia 2012;18:843-850.

[151] Hoots WK. Emergency care issues in hemophilia. World Federation of Haemophilia 2007. Publikacja dostępna na stronie internetowej www.wfh.org.

[152] Szczepanik AB, Misiak A, Ratajczak J, Luterek KM, Windyga $\mathrm{J}$, Meissner AJ. Endoskopowa terapia iniekcyjna skojarzona z doŜylnym stosowaniem omeprazolu w leczeniu krwawiących wrzodów trawiennych. Pol Przegl Chir 2006;7:284-294.

[153] Brewer AK, Roebuck EM, Donacie M, et al. The dental management of adult patients with haemophilia and other congenital bleeding disorders. Haemophilia 2003;9:673-677

[154] Ghosh K, Madkaikar M, Jijina F, Shetty S. Fractures of long bones in severe haemophilia. Haemophilia 2007;13:337-339.

[155] Lee CA, Chi C, Pavord SR, et al., UK Haemophilia Centre Doctors' Organization. The obstetric and gynaecological management of women with inherited bleeding disordersreview with guidelines produced by a taskforce of UK 
Haemophilia Centre Doctors' Organization. Haemophilia 2006;12(supl. 4):301-336.

[156] Bolton-Maggs PH, Perry DJ, Chalmers EA, et al. The rare coagulation disorders-review with guidelines for management from the United Kingdom Haemophilia Centre Doctors' Organisation. Haemophilia 2004 Sep;10 (5):593-628.

[157] Chalmers E, Williams M, Brennand J, Liesner R, Collins P, Richards M, on behalf of the Paediatric Working Party of the United Kingdom Haemophilia Doctors' Organization. Guideline on the management of haemophilia In the fetus and neonate. British Journal of Haematology 2011;154:208-2015.

[158] Coppola A, Windyga J, Tufano A, Yeung C, Di Minno MN. Treatment for preventing bleeding in people with haemophilia or other congenital bleeding disorders undergoing surgery. Cochrane Database Syst Rev 2015 Feb 9;2:CD009961.

[159] Batorowa A, Martinowitz U. Continuous infusion of coagulation factors. Haemophilia 2002;8(supl. 3):170-177.

[160] Batorova A, Martinowitz U. Continuous infusion of coagulation factors: current opinion. Curr Opin Hematol 2006;13(supl. 5):308-315.

[161] Rodriguez-Marchan EC. Haemophilic synovitis: basic concepts. Haemophilia 2007;13(supl. 3):1-3.

[162] Hoots WK, Rodriguez N, Boggio L, Valentino LA. Pathogenesis of haemophilic synovitis: clinical aspects. Haemophilia 2007;13(supl. 3):4-9.

[163] Valentino LA, Hakobyan N, Rodriguez N, Hoots WK. Pathogenesis of haemophilic synovitis: experimental studies on blood-induced joint damage. Haemophilia 2007;13(supl. 3):10-13.

[164] Goddard NJ, Mann H. Diagnosis of haemophilic synovitis. Haemophilia 2007;13(supl. 3):14-19.

[165] Verma N, Valentiono LA, Chawla A. Arthroscopic synovectomy in haemophilia: indications, technique and results. Haemophilia 2007;13(supl. 3):38-44.

[166] Rodriguez-Marchan EC, Quintana M, de la Corte-Rodriguez $\mathrm{H}$, Coya J. Radioactive synoviorthesis for the treatment of haemophilic synovitis. Haemophilia 2007;13(supl. 3):32-37.

[167] Rodriguez-Marchan EC. Total joint arthroplasty: the final solution for knee and hip when synovitis could not be controlled. Haemophilia 2007;13(supl. 3):49-58.

[168] Stephensen D. Rehabilitation of patients with haemophilia after orthopaedic surgery: a case study. Haemophilia 2005;11(supl. 1):26-29.

[169] Peacock K. Quality of life before and after surgery: mobility issues, the fear of surgery, inpatient recovery and outpatient rehabilitation. Haemophilia 2005;11(supl. 1): 30-31.

[170] Rodriguez-Merchan EC, Gomez-Cardero P. Pathological fracture of a true tumour mimicking a haemophilic pseudotumor. Haemophilia 2005;11:188-190.

[171] Valentino LA, Martinowitz U, Doolas A, Murali P. Surgical excision of a giant pelvic pseudotumour in a patient with haemophilia A. Haemophilia 2006;12:541-544.

[172] Windyga J, Grabarczyk P, Stefańska E, et al. Częstość zakaźeń HCV, HBV i HIV w populacji chorych na ciężką hemofilię w Polsce. Przegląd Epidemiologiczny 2008;62 (2):415-423.

[173] Franchini M, Nicolini N, Capra F. Treatment of hepatitis C in hemophiliacs. American Journal of Hematology 2006;81:696-702.

[174] Puetz J, Thrower M, Kane R, Bouhasin J. Combination therapy with ribavirin and interferon in a cohort of children with hepatitis $C$ and haemophilia followed at a pediatric haemophilia treatment center. Haemophilia 2004;10:87-93.
[175] Zoulim F, Bailly F. New approaches to the management of hepatitis C in haemophilia in 2012. Haemophilia 2012;18 (Suppl 4):28-33.

[176] Wilde JT, Mutimer D, Dolan G, et al. UKHCDO guidelines on the management of HCV in patients with hereditary bleeding disorders 2011. Haemophilia 2011;17:e877-e883.

[177] Afdhal N, Reddy KR, Nelson DR, et al., ION-2 Investigators. Ledipasvir and Sofosbuvir for previously treated HCV genotype 1 infection. NEJM 2014;370:1483-1493.

[178] Sulkowski MS, Gardiner DF, Rodriguez-Torres M, et al., AI444040 Study Group. Daclatasvir plus sofosbuvir for previously treated or untreated chronic HCV infection. N Engl J Med 2014;370:211-221.

[179] Maor I, Bashari D, Kenet G, et al. Non-invasive biomarkers of liver fibrosis in haemophilia patients with hepatitis C: can you avoid liver biopsy? Haemophilia 2006;12:372-379.

[180] Detrait M, Pothen D, Brenard R, Starkel P, Hermans C. Feasibility, safety and cost-effectiveness of transjugular liver biopsy following major surgery in patients with haemophilia. Haemophilia 2007;13:588-592.

[181] Windyga J, Proniewski J, Stefańska E, Szczepanik AB, Brojer E, Grabarczyk P. Consequences of long-lasting HCV infection in haemophiliacs - what can we learn from ultrasonography and endoscopy evaluation? Haemophilia 2008;14(supl. 2):42.

[182] Makris M, Baglin T, Dusheiko G, et al. Guidelines on the diagnosis, management and prevention of hepatitis in haemophilia. Haemophilia 2001;7:339-345.

[183] Alter HJ. Management of hepatitis virus infection. Haemophilia 2008;14(supl. 3):26-32.

[184] Millar CM, Makris M. Dealing with the uncertain risk of variant Creutzfeldt-Jakob disease transmission by coagulation replacement products. Br J Haematol 2012;158:442-452.

[185] Will RG, Ironside JW, Zeidler M, et al. A new variant of Creutzfeldt-Jakob disease in the UK. Lancet 1996;347:921-925.

[186] Millar CM. vCJD and hemophilia. W: Lee CA, Berntorp EE, Hoots WK, reds. Textbook of Hemophilia. Third Edition, Wiley Blackwell; 2014. p. 277-282.

[187] Peden A, McCardle L, Head MW, et al. Variant CJD infection in the spleen of a neurologically asymptomatic UK adult patient with haemophilia. Haemophilia 2010;16:296-304.

[188] Humphries TJ, Kessler CM. Managing chronic pain in adults with ahemophilia: current status and call to action. Haemophilia 2015;21:41-51.

[189] Holstein K, Klamroth R, Richards M, Carvalho M, PérezGarrido R, Gringeri A. European Haemophilia Therapy Standardization Board. Pain management in patients with haemophilia: a European survey. Haemophilia 2012;18:743-752.

[190] Larsson SA. Life expectancy of Swedish haemophiliacs, 1831-1980. Br J Haematol 1985;59:593-602.

[191] Darby SC, Kan SW, Spooner RJ, et al. Mortality rates, life expectancy, and causes of death in people with haemophilia A or B in the United Kingdom who were not infected with HIV. Blood 2007;110:815-825.

[192] Dolan G. The challenge of an ageing hemophilic population. Haemophilia 2010;16(suppl. 5):11-16.

[193] Tuinenburg A, Mauser-Bunschotten EP, Verhaar MC, Biesma DH, Schutgens REG. Cardiovascular disease in patients with hemophilia. J Thromb Haemost 2009;7:247-254.

[194] Mauser-Bunschoten EP, Fransen Van De Putte DE, Schutgens RE. Co-morbidity in the ageing haemophilia patient: the down side of increased life expectancy. Haemophilia 2009;15:853-863.

[195] Mannucci PM, Mauser-Bunschoten EP. Cardiovascular disease in haemophilia patients: a contemporary issue. Haemophilia 2010;16(Suppl 3):58-66. 
[196] Hermans C, de Moerloose P, Dolan G. Clinical management of older persons with haemophilia. Crit Rev Oncol/Hematol 2014;89:197-206.

[197] Mannucci PM, Schutgens REG, Santagostino E, MauserBunschotten EP. How I treat age-related morbidities in elderly persons with hemophilia. Blood 2009;114:5256-5263.

[198] Konkle BA, Kessler C, Aledort L, et al. Emerging clinical concerns in the ageing haemophilia patient. Haemophilia 2009;15:1197-1209.

[199] van de Putte DEF, Fischer K, Pulles AE, et al. Non-fatal cardiovascular disease, malignancies, and other comorbidity in adult haemophilia patients. Thromb Res 2012;130:157-162
[200] Zawilska K, Podolak-Dawidziak M. Therapeutic problems in elderly patients with hemophilia. Pol Arch Med Wewn 2012;122:567-576.

[201] Mauser-Bunschotten EP, Bijlsma W, Roosendaal G, Schutgens REG. Cataract surgery in haemophilia. Haemophilia 2013;19:e371-e372.

[202] Mauser-Bunschotten EP, Schutgens REG. Old age medicine and hemophilia. W: Lee CA, Berntorp EE, Hoots WK, reds. Textbook of Hemophilia. Third Edition, Wiley Blackwell; 2014. p. 154-162.

[203] Foley CJ, Nichols L, Jeong K, Moore CG, Ragni MV. Coronary atherosclerosis and cardiovascular mortality in haemophilia. J Thromb Haemost 2010;8:208-211. 